\title{
Central Andean Crustal Structure from Receiver Function Analysis
}

Jamie Ryan ${ }^{1 *}$; jgeoryan@email.arizona.edu

Susan Beck ${ }^{1}$; slbeck@email.arizona.edu

George Zandt ${ }^{1}$; gzandt@email.arizona.edu

Lara Wagner²; lwagner@carnegiescience.edu

Estela Minaya33; eminaya@observatoriosancalixto.com

Hernado Tavera ${ }^{4}$; hernando.tavera@igp.gob.pe

* Corresponding author

\author{
Affiliations \\ ${ }^{1}$ University of Arizona; \\ Department of Geosciences \\ 1040 4th St. \\ Tucson, AZ, USA 85721 \\ ${ }^{2}$ Carnegie Institution for Science; \\ Department of Terrestrial Magnetism \\ Carnegie Institution of Washington \\ 5241 Broad Branch Road, NW \\ Washington, DC, USA 20015-1305 \\ ${ }^{3}$ Observatorio San Calixto; \\ Calle Indaburo 944 \\ Casilla: 12656 \\ La Paz, Bolivia \\ ${ }^{4}$ Instituto Geofísico del Perú \\ Calle Badajoz \#169 \\ Mayorazgo IV Etapa \\ Ate Vitarte \\ Lima, Peru
}




\section{Abstract}

The Central Andean Plateau $\left(15^{\circ}-27^{\circ} \mathrm{S}\right)$ is a high plateau in excess of $3 \mathrm{~km}$ elevation, associated with thickened crust along the western edge of the South America plate, in the convergent margin between the subducting Nazca plate and the Brazilian craton. We have calculated receiver functions using seismic data from a recent portable deployment of broadband seismometers in the Bolivian orocline $\left(12^{\circ}-21^{\circ} \mathrm{S}\right)$ region and combined them with waveforms from 38 other stations in the region to investigate crustal thickness and crust and mantle structure. Results from the receiver functions provide a more detailed map of crustal thickness than previously existed, and highlight mid-crustal features that match well with prior studies. The active volcanic arc and Altiplano have thick crust with Moho depths increasing from the central Altiplano $(65 \mathrm{~km})$ to the northern Altiplano $(75 \mathrm{~km})$. The Eastern Cordillera shows large along strike variations in crustal thickness. Along a densely sampled SW-NE profile through the Bolivian orocline there is a small region of thin crust beneath the high peaks of the Cordillera Real where the average elevations are near $4 \mathrm{~km}$, and the Moho depth varies from 55 to $60 \mathrm{~km}$, implying the crust is undercompensated by $\sim 5 \mathrm{~km}$. In comparison, a broader region of high elevations in the Eastern Cordillera to the southeast near $\sim 20^{\circ} \mathrm{S}$ has a deeper Moho at $\sim 65-70 \mathrm{~km}$ and appears close to isostatic equilibrium at the Moho. Assuming the modern-day pattern of high precipitation on the flanks of the Andean plateau existed since the late Miocene, we suggest that climate induced exhumation can explain some of the variations in present day crustal structure across the Bolivian orocline. We also suggest that south of the orocline at $\sim 20^{\circ} \mathrm{S}$, the thicker and isostatically compensated crust is due to the absence of erosional exhumation and the occurrence

Keywords: crustal thickness, Central Andes, receiver functions, isostasy

\section{Introduction}

The Central Andean Plateau (CAP) is the second highest plateau on Earth and is associated with a convergent margin where the oceanic Nazca plate subducts beneath the continental South American plate. The central Andes are an ideal place to study convergent margin processes and the structure of overthickened continental crust. The CAP, defined as the region over $3 \mathrm{~km}$ in elevation, consists of three distinct provinces from west to east; the active volcanic arc of the Western Cordillera, the internally drained Altiplano and the inactive fold and thrust belt of the Eastern Cordillera (McQuarrie and DeCelles, 2001). Further east is the active fold and thrust belt of the Subandean zone, and the modern foreland of the Beni basin. Previous 
71 studies have shown that the CAP is characterized by thick continental crust and greater than 275

$72 \mathrm{~km}$ of crustal shortening in the back-arc region (McQuarrie et al., 2005; McQuarrie et al., 2008;

73 Oncken et al., 2006; Eichelberger, et al., 2015 and other references therein).

74 In 2010 an array of 50 broadband seismometers was deployed for two years in northwest

75 Bolivia and southern Peru as part of the Central Andean Uplift and Geodynamics of High

76 Topography (CAUGHT) project funded by the NSF-Continental Dynamics program. In this

77 study we use data recorded by the CAUGHT seismic array, combined with additional data from

78 permanent seismic stations and previous portable broadband deployments, to determine the

79 crustal thickness and structure of the crust in the Bolivian orocline section of the central Andes in

80

81

82

83

84

85

86

87

88

89

90

91

92

93

northern Bolivia and southern Peru. Our goal in this paper is to provide more detailed images of

the crustal structure of the northern and central Andean Plateau that can be used as constraints to gain insights into possible mechanisms of plateau formation and uplift. We also identify two sections of undercompensated crust in the Eastern Cordillera that may be a result of their proximity to regions of higher precipitation.

\section{Tectonic Setting}

The CAP region of northwestern Bolivia and Southern Peru extends roughly $400 \mathrm{~km}$ from the volcanic arc to the Subandean zone. The Altiplano is an internally drained basin, with average elevations of $\sim 3.8-4 \mathrm{~km}$, between the high peaks of the Western and Eastern Cordilleras that reach up to $6 \mathrm{~km}$. Volcanoes define the present-day extent of the magmatic arc in the Western Cordillera (Fig. 1). The Eastern Cordillera along this section of the Andes is an inactive fold and thrust belt that contains Triassic and Miocene plutons (Isacks, 1988; Kley, 1999; McQuarrie and DeCelles, 2001; Gilles et al., 2006). The Interandean zone, located between the 
94 Eastern Cordillera and Subandean zone, is a region that was uplifted by imbricated basement

95 material between 10 and $5 \mathrm{Ma}$, as shortening propagated east into the active, thin-skinned fold

96 and thrust belt in the Subandean zone (Kley,1996; McQuarrie et al., 2005).

97 Of interest in this study is the northern portion of the CAP, from roughly $12^{\circ}-20^{\circ} \mathrm{S}$ and

$63^{\circ}-72^{\circ} \mathrm{W}$. This region lies in one of the widest sections of the CAP at the Arica Bend, and has

100

101

102

103

104

105

106

107

108

109

110

111

112

113

114

115

116

undergone significant upper crustal shortening in the backarc. Numerous studies have found higher amounts of shortening, up to $350 \mathrm{~km}$, in the orocline region than in either the Puna region to the south, where backarc shortening is closer to $\sim 200 \mathrm{~km}$, or in the Andean region farther north in Peru where shortening is $\sim 175 \mathrm{~km}$ (Kay and Kay, 1993; Allmendinger and Gubbels, 1996; Kley and Monaldi, 1998; McQuarrie et al., 2008; DeCelles, et al., 2011; Gotberg et al., 2010). McQuarrie (2008) partitions the overall upper crustal shortening between $14^{\circ}$ and $18^{\circ} \mathrm{S}$ into the tectonic provinces along the orocline axis in roughly the following amounts: $39 \mathrm{~km}$ in the Altiplano, $171 \mathrm{~km}$ in the Eastern Cordillera and Interandean zones, and $66 \mathrm{~km}$ in the Subandean zone. Upper crustal shortening has occurred in the region, at an essentially constant rate, from roughly 45-0 Ma (McQuarrie et al., 2008; Eichelberger and McQuarrie, 2015). While exhumation rates are fairly consistent with proposed shortening models from 45-0 Ma, there is proposed surface uplift of $\sim 1.5-3 \mathrm{~km}$ since $10 \mathrm{Ma}$ with little associated upper-crustal shortening in the Eastern Cordillera and continued exhumation of the Eastern Cordillera from 15-0 Ma

(Gillis et al., 2006; Garzione et al., 2006; McQuarrie et al., 2008; Leier, et al., 2013).

Recent climate studies have instead suggested that uplift of the region in the 15-0 Ma time frame was less than one kilometer (Poulsen et al., 2010; Insel at al., 2012).

These differences in the timing of upper-crustal shortening and exhumation, as well as $12 \mathrm{Ma}$ low relief surfaces identified throughout the Eastern Cordillera, have been used to argue 
117 that two separate phases of uplift occurred, one associated with upper-crustal shortening that 118 caused initial uplift of the Eastern Cordillera, and another that led to a rapid rise of the Eastern 119 Cordillera and Altiplano in the last $10 \mathrm{Ma}$ (Isacks, 1988; Gubbels et al., 1993; Kennan et al., 120 1997; Husson and Sempere, 2003; Gillis et al., 2006; Hoke and Garzione, 2008; Whipple and

121 Gasparini, 2014). To account for the rise of the Eastern Cordillera without upper crustal

122 shortening since $\sim 10 \mathrm{Ma}$ (e.g. Isacks, 1988), mechanisms have been proposed that include under123 plating of fore-arc material, under-thrusting of the Bolivian craton, removal of material from the 124 lower crust and upper mantle and lower crustal flow (Baby et al., 1997; Giese, et al., 1999; 125 Allmendinger, 1996, Husson and Sempere, 2003; Oncken, et al., 2006, Garzione, et al. 2006, 126 Molnar and Garzione, 2007, Lamb, 2011). Foundering, or lithospheric removal, has also been 127 postulated as a means of creating cycles of orogenic uplift in addition to regional high 128 topography such as that seen in the Western U.S. or Andean Plateau. This process involves 129 eclogitic roots that form under mountain systems, with their removal being a potential driving 130 force in the creation of high mountain systems as an attempt to achieve isostatic equilibrium 131 (Yuan et al., 2000; Yuan et al., 2002; Zandt et al., 2004; Shurr et al., 2006; Molnar and Garzione, 132 2007; Garzione et al., 2008; Kay and Kay, 1993; DeCelles et al., 2009). Other studies have 133 argued against the need for foundering to cause large-scale regional uplift, and have instead 134 supported crustal thickening models that create high topography with minor or no contributions 135 from lithospheric removal (Lamb, 2011; Barnes et al., 2012; Hindel et al., 2005; Eichelberger et 136 al., 2015 and other references therein).

\section{$137 \quad \underline{2.1 \text { Previous Geophysical Studies }}$}

Previous geophysical work in the central Andes has shown that there are significant

139 changes in crustal character across the width of the Andes, with crustal thicknesses ranging up to 
$14070 \mathrm{~km}$ or more underneath the Western and Eastern Cordilleras, up to $\sim 60 \mathrm{~km}$ underneath the

141 Altiplano and as little as $35 \mathrm{~km}$ further east into the Bolivian craton (Dorbath et al., 1991;

142 Dorbath et al., 1993; Beck and Zandt, 2002; Yuan et al., 2002; McGlashan et al., 2008). Most of

143 these studies overlap slightly with or are south of our study area. There are large magma bodies

144 documented to the south in the Altiplano-Puna region (Chmielowski et al., 1999; Zandt et al.,

145 2003, Ward et al., 2013), and evidence for low-angle thrust faults with little to no surface

146 representation between $\sim 21-24^{\circ}$ S (Wigger, et al., 1994; Schmitz and Kley, 1997). Further, the

147 thick crust underneath the central Andes near $19-20^{\circ} \mathrm{S}$, including the 5-6 km elevations of the

148 Western and Eastern Cordillera peaks, appear to be in isostatic equilibrium (Beck and Zandt,

149 2002; Yuan et al., 2002). High seismic velocities under the Western Cordillera match well with

150 those expected of mafic material thought to be associated with active arcs, and are not present in

151 either the Eastern Cordillera or underneath the Altiplano (Myers et al., 1998; Graeber and Asch,

152 1999).

153

A recent regional study further to the north of our study area, in southern Peru $(\sim 13-$

$15417^{\circ} \mathrm{S}$ ), found crust up to $75 \mathrm{~km}$ thick, and a positive impedance contrast at $40 \mathrm{~km}$ depth that the

155 authors interpreted as possible under-thrusting of the Brazilian Shield underneath the Eastern

156 Altiplano (Phillips et al., 2012; Phillips et al., 2014). These studies cover an area between the

157 flat-slab subduction segment in central Peru, and the normal dipping $\left(30^{\circ}\right)$ slab segment in

158 southern Peru; $\sim 13-16^{\circ} \mathrm{S}$ and $\sim 75-70^{\circ} \mathrm{W}$. In these studies, the Moho underneath the Altiplano has

159 also been shown to have minimal topography, and maintains a thickness of $70 \mathrm{~km}$ from north to 160 south.

In our study region, Dorbath et al. (1993) estimated lithospheric structure based on local

162 tomography along a line of stations across the Andes in Bolivia that corresponds to our densest 
163 line of stations (Figure 2a, B-B'). They estimated the crustal thickness to be $60 \mathrm{~km}$ under the

164 Altiplano and $50 \mathrm{~km}$ under the Eastern Cordillera based on changes in P-wave seismic velocity.

165 However, there are few other locally derived determinations of crustal thickness in the CAP in

166 northern Bolivia or southern Peru where there are high elevations and large amounts of crustal

167 shortening.

168 A number of recent studies have developed continental-scale crustal thickness models for

169 South America using seismic and gravity techniques (Feng et al., 2007; Lloyd et al., 2010; van

170 der Meijde et al., 2013; Assumpção et al., 2013; Chulick et al., 2013) but there is limited data on

171 the depth to Moho in the central and northern Altiplano. These studies show a smooth Moho

172 with thick crust $(\sim 60-70 \mathrm{~km})$ beneath the high elevations of the Andes and lower elevations (30-

$17340 \mathrm{~km}$ ) beneath the low elevations east of the Subandean zone. The results from our study will

174 improve continental scale models in the future.

175

176 3. Data

177

178 deployment was part of a larger collaborative National Science Foundation Continental

179 Dynamics funded project, and consisted of 50 STS-2 broadband seismometers deployed in a

180 temporary network for two years (2010-2012) in northwest Bolivia and southern Peru (Fig. 2a).

181 We have supplemented that data with additional records from the BANJO-SEDA deployment;

182 the permanent GSN station near La Paz, Bolivia (LPAZ); an array installed by the Observatorio

183 San Calixto in Bolivia; stations from the Integrated Plate Boundary Observatory Chile (IPOC);

184 an international project by GFZ Potsdam; and a new permanent station installed in northern

185 Chile by the Chile National Network (Fig. 2a; Table 1). We have used both teleseismic and local 
earthquakes recorded by the CAUGHT temporary network and other nearby stations in this study.

We used teleseismic waveforms from events $(\mathrm{Mw}>5.5)$ in the direct-P and PP distance ranges of $\sim 30-95^{\circ}$ and $\sim 100-150^{\circ}$, respectively. The distribution and location of the events used for calculating the receiver functions in this study are shown in Figure 2b. We identified 343 earthquakes with both a strong first arrival and high signal-to-noise ratios (greater than 10:1) for use in this study (Fig. 2b). For the permanent station LPAZ we used events over a 10-year period. Excess waveforms from the LPAZ station at dominant back-azimuths were removed to ensure even back-azimuthal distribution. Many of the stations used in this study had similar back-azimuthal coverage, despite their differing deployment times, and some stations had coverage on par with permanently deployed stations as shown in binned back-azimuth plots (Fig. 3). A figure showing examples of the raw data, before binning, is available in Supplemental Figure 1. While stations from the network deployed by the Observatorio San Calixto were used in this study, we had a limited number of receiver functions (10 or less for each station) because the stations had been recording for 6 months or less at the time of data collection.

In order to constrain the average $\mathrm{Vp} / \mathrm{Vs}$ ratio for the crust we use Wadati diagrams calculated using 9 local earthquakes with depths $<50 \mathrm{~km}$. For our Wadati diagram we have used 200 local waveforms that were chosen to be less than $300 \mathrm{~km}$ distance from the line of densest station spacing (B-B', Fig. 2a) in the orocline region of the CAUGHT array to ensure that the direct-P was the first arrival. Of the nine events used, about half were located off the west end of the B-B' CAUGHT line and the rest were distributed along its length. The local waveforms had distinct $\mathrm{P}$ and $\mathrm{S}$-wave first arrivals so that differential travel times could be determined. 


\subsection{Receiver function and CCP stacking method}

Teleseismic waveforms were used to calculate receiver functions, which isolate

212 converted phases from velocity discontinuities beneath a seismic station (Langston, 1979).

213 Radial and tangential receiver functions are calculated by deconvolving the vertical component

214 from the radial and tangential components of our teleseismic waveforms. P-to-S conversions at 215 velocity discontinuities result in arrivals following the direct P-wave arrivals, which are visible 216 on the radial component of the receiver function (Ammon et al., 1990; Ammon, 1991; Cassidy, 217 1992). Tangential receiver functions can provide additional information because in the absence 218 of anisotropy or dipping structures, they should show no energy.

219 In order to calculate our receiver functions, we first filtered the waveforms using a 220 Butterworth bandpass filter with corners at 0.1 and $5 \mathrm{~Hz}$ to isolate the initial P-wave arrival and 221 eliminate any long-period noise. After rotation of the horizontal components into the radial222 transverse reference frame we applied the iterative time-domain deconvolution technique of 223 Liggoría and Ammon (1999) using a Gaussian pulse of 2.5 (corner frequency $\sim 1 \mathrm{~Hz}$ ). We 224 allowed up to 400 iterations in the deconvolution. Any receiver functions showing initial 225 negative troughs, very high amplitudes after the first arrival, or significant resonance and ringing 226 in their coda were discarded. Final quality control consisted of elimination of any receiver 227 functions with more energy (higher amplitude) on the transverse receiver function than the radial 228 receiver function at the time of the initial P-wave arrival. In our final data set we have 2000 229 receiver functions from 343 teleseismic earthquakes, corresponding to $\sim 20$ receiver functions per 230 station (Fig. 2b). 
Teleseismic receiver functions used in this study were stacked using the common conversion point (CCP) method, which stacks receiver functions in subsurface bins based on the location of the P-to-S conversion to increase the signal to noise ratio (Dueker and Sheehan, 1997;

234 Sheehan, et al., 2000). This stacking method allowed us to share information between adjacent 235 bins; a portion of the signal amplitude of a source bin is shared with nearby bins in an effort to 236 smooth the resulting model and close small gaps in receiver function coverage. A phase237 weighting filter was applied to the stacks to reduce signal-generated noise (Frassetto et al., 238 2010), and any bins sampled by fewer than five ray paths were removed. An example of the 239 effects of different phase-weighting strengths is shown in supplemental Fig. S3. All the receiver 240 functions are corrected for elevation and the stacks are plotted as depth below sea level. During the stacking process all of the receiver functions were migrated from the time 242 domain into depth using a 3D S-wave velocity model determined from a combination of the 243 ambient noise tomography study by Ward et al., (2013) above $60 \mathrm{~km}$, and the IASP91 global 244 model below $60 \mathrm{~km}$. The ambient noise model used periods for 8-40 seconds (Ward et al., 2013). 245 We used a constant $\mathrm{Vp} / \mathrm{Vs}$ ratio of 1.75 in the upper $60 \mathrm{~km}$, and a ratio of 1.80 below $60 \mathrm{~km}$ to 246 calculate a P-wave velocity model from the 3D S-wave velocity model. We used local 247 earthquakes and the Wadati diagram method, to determine the average $\mathrm{Vp} / \mathrm{Vs}$ ratio of 1.75 in the 248 mid to upper crust (Whitcomb et al., 1917; Fig. 4). This also matches well with previous 249 estimates of $\mathrm{Vp} / \mathrm{Vs}$ ratios calculated for the northern CAP (Cunningham and Roecker 1986;

250 Dorbath et. al. 1996; Chulick et. al. 2012). While it is common the use the HK method (Zhu and 251 Kanamori, 2000) to estimate the $\mathrm{Vp} / \mathrm{Vs}$ for individual stations, we found the HK results for our 252 stations to be generally unreliable (a sample HK plot is shown in supplemental Fig. S4).

253 Receiver functions were back-projected through this 3D volume starting with a 1D average of 
254 the entire volume to produce an initial ray path. Refinement of that ray path was then done using

255 the velocities sampled along the initially calculated ray path through the $3 \mathrm{D}$ velocity volume

256 (Frassetto and Thybo, 2013).

257 Receiver functions were stacked along dozens of different cross-section profiles, of

258 which we present the five cross-sections, through the regions of the volume with the highest

259 density of station coverage (Fig. 5, Fig. 6a-d). We used rectangular bins that can vary both along-

260 profile and perpendicular to the profile line in order to maximize the coverage of each cross-

261 section. Along the cross-section where we have the densest station spacing we defined the bins

262 with a $15 \mathrm{~km}$ width along-profile and $30 \mathrm{~km}$ width perpendicular to the profile. Our dense profile

263 has two trends; B-B' SW of the bend has a trend of $32^{\circ}$ and NE of the bend has a trend of $58^{\circ}$

264 (Fig. 5). For the other cross-section profiles we used $50 \mathrm{~km}$ bins to better match the station

265 spacing: a trend of $60^{\circ}$ was used for the northernmost profile (Fig. 6a), a trend of $90^{\circ}$ was used to

266 re-process the original BANJO-SEDA line (Fig. 6b), trends of $132^{\circ}$ and $172^{\circ}$ were used to fit the

267 Western Cordillera (Fig. 6c), and trends of $130^{\circ}$ and $170^{\circ}$ were used along the high topography

268 of the Eastern Cordillera profile (Fig. 6d). Our bins average about a dozen piercing points each at

$26950 \mathrm{~km}$ depth, and we eliminate bins with less than 5 rays contributing to the stack

270 (Supplementary Figure S2).

$271 \quad$ We used the CCP stack cross-sections ( $\sim 25$ orthogonal and $\sim 10$ parallel sections) with 50

$272 \mathrm{~km}$ bins through the entire volume to calculate the depth of the Moho, not just the five cross-

273 sections shown in Figures 5 and 6, in conjunction with single station stacks to identify the

274 conversion from the continental Moho, which is usually the strongest velocity contrast in the

275 receiver functions. We identified the P-to-S conversion from the Moho (relative to sea level) and

276 several other discontinuities in the crust and upper mantle. We made a map of the depth to the 
277 Moho and used the same volume of stacked receiver functions and nearest neighbor interpolation

278 between adjacent bins to contour our map (Fig. 7). Adjacent areas outside of the station coverage

279 were constrained based on the regional scale Moho map by Tassara et al., (2006). The Ps

280 piercing points and the bin sharing geometry at $50 \mathrm{~km}$ depth is shown in supplemental Figure S2

281 and provide a qualitative measure of the data coverage for the Moho map. While we note that

282 some bins are based on interpolation between stations, the coverage is significantly better than

283 previously available.

284 The uncertainty in the depth of a P-to-S conversion is a result of the trade-off between 285 depth to a conversion layer and the velocity structure along the ray. Small changes in the Vp/Vs 286 ratio have been shown to create large differences in the calculated depth of the converted arrival 287 (Zhu and Kanamori, 2000), so uncertainty is reduced significantly by using a well-constrained $288 \mathrm{Vp} / \mathrm{Vs}$ ratio. Migrated receiver functions are less sensitive to changes in the absolute P-wave 289 velocity, with changes of $\mathrm{Vp}$ model used, from a simple two-layer model to one constrained 290 using ambient-noise tomography, influencing arrival depth by less than $\pm 0.5 \mathrm{~km}$. Using a Wadati 291 diagram, we have identified the best-fit average mid to upper crustal Vp/Vs ratio (1.75) in the 292 region to within 0.01 , which reflects an uncertainty of about $\pm 1 \mathrm{~km}$ at $60 \mathrm{~km}$ depth (Fig. 4).

293 However, larger errors are possible as the $\mathrm{Vp} / \mathrm{Vs}$ ratio could change locally, and we have little 294 constraint on the $\mathrm{Vp} / \mathrm{Vs}$ ratio below $\sim 40 \mathrm{~km}$. In addition, dipping structures, or the presence of 295 regions of high anisotropy, could also contribute significantly to the uncertainty of our arrivals. 
Our results are shown in Figures 5 and 6 as CCP cross-sections and in Figure 7 as a

Moho depth map relative to sea level. Along our densest instrumented line, CAUGHT B-B' (Fig. 2a, 5), our CCP cross-section shows a prominent continental Moho increasing in depth from $\sim 40$ $\mathrm{km}$ on the eastern edge of the active fold and thrust belt to $\sim 60 \mathrm{~km}$ on the eastern edge of the high plateau. The Moho depth reaches nearly $70 \mathrm{~km}$ in the center of the Altiplano and appears to remain deep under the western Cordillera but its identification there is complicated by complex crustal structure in the transition zone between the arc and western edge of the plateau. Beneath this transition zone the receiver function stacks show a complex layered structure suggestive of multiple low velocity layers in the crust and likely includes multiples from the prominent low velocity zone at $\sim 15 \mathrm{~km}$ depth (TLVZ). The continental Moho location under the forearc is not clear in the CCP stacks. There is a prominent positive arrival at $\sim 70 \mathrm{~km}$ depth but it is too deep to be the continental Moho and too flat to be the oceanic Moho of the subducting slab. We suggest the continental Moho here is weak due to partial serpentinization of the mantle above the slab as observed in other subduction zones (Wada, et al., 2008 and references therein).

The cross-section A-A', across southern Peru just south of the Peruvian flat slab, has limited coverage in the forearc and the narrower fold and thrust belt at this latitude (Fig. 6a). The Moho depth is $60-65 \mathrm{~km}$ under the plateau, shallowing to $\sim 50 \mathrm{~km}$ under the Subandes. There are complexities and low-velocity zones associated with the wide volcanic arc in this region. Farther south the C-C' line (Fig. 6b) follows the BANJO-SEDA line interpreted in Yuan et al. (2000,2002) and Beck and Zandt (2002). The CCP stack cross-section along this line utilizes a few additional stations and uses PP phases, in addition to the P phases that were used in Beck and Zandt, (2002). Our results are very similar to those found along similar cross-sections, previously. This cross-section shows similar crustal thicknesses to line B-B' in the Western 
322 Cordillera and Altiplano, and a $40 \mathrm{~km}$ thick crust in the Subandean zone, but the Moho under the

323 Eastern Cordillera is significantly deeper, $\sim 65-70 \mathrm{~km}$.

Along the strike of the Western Cordillera, line D-D' (Fig. 6c), the Moho arrival is

325 indistinct along most of the profile. There is a high amplitude arrival at $70-75 \mathrm{~km}$ depth where

326 the cross-section intersects line B-B', but as we previously stated it is difficult to unambiguously

327 identify the Moho among the multiple layers. However, north of $18^{\circ} \mathrm{S}$ there is a faint continuous

328 arrival at $70-75 \mathrm{~km}$ that may mark a weak or gradational Moho under the active arc. South of

$32918^{\circ} \mathrm{S}$ along the western Cordillera, the CCP stacks show layering that is unlikely to be due to

330 multiples, suggesting complex Moho structure (Fig. 6d). While an accurate Moho depth is

331 difficult to pinpoint, it is unlikely that either the arrival at $90 \mathrm{~km}$ or the shallowest positive

332 conversion at $40 \mathrm{~km}$ represent Moho depths.

333

The CCP cross-section along the strike of the Eastern Cordillera (line E-E', Fig. 6d)

334 shows a continuous high-amplitude Moho at depths of 60-70 km at the NW and SE ends and a

335 broad shallowing to depths of $55-60 \mathrm{~km}$ in the center. At the southern end, in the location of the

336 BANJO-SEDA network there is at least locally a deep Moho beneath the Eastern Cordillera

$337(\sim 65-70 \mathrm{~km})$. A deeper Moho $(\sim 70 \mathrm{~km})$ is also observed to the northwest in the Eastern

338 Cordillera as the Altiplano pinches out in southern Peru. In between the Moho has a broad

339 upwarp defining locally thinner crust with the Moho reaching a minimum depth of $55 \mathrm{~km}$ just

340 north of La Paz (Fig. 6d).

Figure 7 shows a smoothed contour map of depth to the Moho beneath our study region using receiver function results under the seismic station array. On the edges, and outside the

343 array, we constrained the depth of Moho from Tassara et al., (2006) who used primarily gravity

344 data in these regions. The map shows Moho depths $<40 \mathrm{~km}$ in the forearc and foreland. The 60 
$345 \mathrm{~km}$ depth contour encompasses most of the high elevations of the plateau. The deepest Moho and thickest crust occurs in southern Peru southwest of Lake Titicaca (Figure 7, “D”). The 45 km, 50

$347 \mathrm{~km}$, and $55 \mathrm{~km}$ contours generally parallel the eastern side of the CAP but with two incursions

348 into the area of highest elevations of the Eastern Cordillera. One is a long wavelength $(\sim 300 \mathrm{~km})$

349 "bowing" of the contours centered at $\sim 17^{\circ} \mathrm{S}$ (Figure 7, "E") and the other is a shorter wavelength $350(\sim 150 \mathrm{~km})$ "bite" into the Altiplano just north of La Paz (Figure 7, "D”), outlining the locally 351 thin crust we highlighted in our earlier description of cross section B-B'.

\subsection{Intra-crustal and uppermost mantle discontinuities}

Along the CAUGHT dense line there are two major upper to mid-crustal conversions that

355 stand out on the CCP cross-sections: a negative polarity arrival underneath the Western

356 Cordillera at a depth between $\sim 15$ (Fig. 5, 6, TLVZ= top of low velocity zone) and a positive

357 polarity arrival underneath the Eastern Cordillera and Subandean zone (Fig. 8; "A" and "B").

358 The negative arrival underneath the Western Cordillera, at $15 \mathrm{~km}$ or less, agrees well with the top

359 of a low velocity zone identified in the ambient noise results of Ward et al., (2013). This

360 negative arrival is also present along the C-C' line (Fig. 6b) and is present along most of the

361 along-strike D-D’ section (Fig. 6c).

362 Underneath the Subandean zone along the B-B' cross-section there is a high amplitude 363 positive conversion at $15 \mathrm{~km}$ that shallows to the east (Figure 8, "A"). There is a similar arrival 364 at shallower depths underlying the Eastern Cordillera (Figure 8, "B"). The same feature appears 365 to be more continuous further south, along the C-C' profile (Figure 6b, "Detachment"). Figure 8 366 shows an enlarged version of this part of the CCP cross-section with an overlay of the balanced 367 structural cross-section of the fold and thrust belt from McQuarrie et al. (2008). We note the 
368 correlation of the positive conversion with the decollement fault at base of the highly faulted and

369 folded layers and suggest the arrival marks the top of the "basement" rocks below the basal fault.

370 Further supporting this interpretation is that the locations of vertical offsets of the arrival closely

371 coincide with the geologic offsets in the structural cross-section.

372 Locally, there are some interesting lower crustal and upper mantle features in our cross-

373 sections. We previously mentioned the complex lower crustal layering in the transition between

374 the Western Cordillera and Altiplano along cross section B-B' (Fig. 5). Along strike farther south

375 cross-section C-C' (Fig. 6b) exhibits the upper crustal low-velocity zone arrival but not the lower

376 crustal and upper mantle ones. We observe some positive amplitude arrivals on the CCP cross-

377 section B-B' at depths of 60 to $200 \mathrm{~km}$ in the vicinity of the slab location based on Slab1.0

378 contours of Hayes, et al., (2012) but we do not image a continuously dipping slab. Another

379 positive conversion arrival is visible underneath the Interandean and Subandean zones and

380 perhaps extending under the Eastern Cordillera at 80-90 km depth along lines B-B' and C-C'

381 (Fig. 5, 6b). We are uncertain whether these seismic discontinuities are older inherited features

382 or active structures related to the underthrusting lithosphere.

383 6. Discussion

We have developed a higher resolution image of the depth to Moho beneath the CAP

385 region of South America than was previously available (Fig. 7) and calculated a crustal thickness

386 residual map based on a simple Airy isostasy model (Fig. 9b and 9c). Overall, our results agree

387 well with the continental-scale models that were mentioned previously, while improving the

388 resolution in many areas (Assumpção et al., 2013; Chulick et al., 2013 and the references

389 therein). We have identified several mid crustal discontinuities across the region that correlate 
390 well with known geology. The significance of the crustal thickness residuals and crustal

391 discontinuities are discussed below starting with the Western Cordillera.

$392 \quad 6.1$ Western Cordillera Crust

393 The orocline region of the Western Cordillera contains a large number of active

394 stratovolcanoes in southern Peru and extending southward on the border between Bolivia and

395 Chile. Our study cannot image the specific plumbing of any one volcanic center or the associated 396 shallow magma bodies, but we can image the overall regional crustal structure beneath the 397 Western Cordillera. Our receiver function stacks show numerous conversions in the crust that 398 produce multiples, making the receiver functions more difficult to interpret. There is a strong 399 negative arrival indicating the top of a low velocity zone at $\sim 5-20 \mathrm{~km}$ under much of the Western 400 Cordillera-Altiplano boundary region (Fig. 5, 6c). Along cross-section A-A' the top of the low401 velocity layer dips from $\sim 5 \mathrm{~km}$ to $15-20 \mathrm{~km}$ toward the east (Fig. 6a). The ambient noise 402 tomography shows S-wave velocities of $\sim 3.0-3.25 \mathrm{~km} / \mathrm{s}$ at $30 \mathrm{~km}$ depth under the active arc 403 (Ward et al., 2013). We observe this decrease in velocity labeled TLVZ, top of low-velocity 404 zone, on cross-section D-D' along the strike of the volcanic arc (Fig. 6c).

405 We observe a sharp increase in velocity in the receiver function images at $\sim 40-45 \mathrm{~km}$ 406 depth along the dense line B-B' (Fig. 5) perpendicular to the strike of the volcanic arc (where we 407 have the smallest bin size) and on C-C', but we do not see this as a continuous discontinuity 408 (limited extent near $71^{\circ} \mathrm{W}$ ) on the along strike cross-section (D-D') with the larger bin spacing 409 (Fig. 6c). Where we see this increase in velocity it may be the bottom of a mid-crustal low 410 velocity zone. This suggests that at least in this region there is a thick region of the crust $(\sim 15-40$ $411 \mathrm{~km}$ ) with very low S-wave seismic velocities. This low S-wave velocity region in the mid-crust 
412 is consistent with high temperatures and some small amount of partial melt assuming an

413 intermediate to felsic composition (Ward et al., 2013).

414 We also observe a strong increase in velocity at $\sim 40-45 \mathrm{~km}$ depth (Fig. 5) with a decrease

415 in velocity at $\sim 60 \mathrm{~km}$ right above the Moho along B-B' suggesting a low velocity region in the

416 lower crust. This might be related to the melting, assimilation, storage and homogenization

417 (MASH) zone proposed by Hildreth and Moorbath (1988) in central Chile. We do not see this

418 lower crust structure everywhere along the arc but it is observed near the intersection of the Peru,

419 Chile, and Bolivia border, beneath the active arc (Fig. 5, 6a).

$420 \quad 6.2$ Detachment structure across the retroarc fold and thrust belt

421

422 structural cross-section across the same region (McQuarrie, et al., 2008) highlights important

423 similarities between the interpreted subsurface geology and our geophysical results along line B-

424 B' (Fig. 8). In the Subandean zone there is very good agreement between the basal detachment in 425 the balanced cross-section of McQuarrie et al. (2008) and a discontinuity (increase in velocity

426 with depth) in our CCP stacks that dips from a depth of $\sim 5 \mathrm{~km}$ at the eastern edge of the

427 Subandean zone to $\sim 15 \mathrm{~km}$ at the boundary with the Interandean zone (Fig. 8, "A"). The

428 discontinuity disappears beneath the Interandean zone presumably because as the detachment

429 goes into the basement there is not an impedance contrast across it. We see a shallow, near

430 horizontal, discontinuity indicating an increase in velocity beneath the Eastern Cordillera at $\sim 5$

$431 \mathrm{~km}$ that corresponds to the basal detachment for the westward verging backthrust zone (Fig. 8,

432 "B"). Beneath the Altiplano we observe a weak amplitude discontinuity at $20 \mathrm{~km}$ that is

433 consistent with a step down in the detachment on a basement ramp in the cross-section of

434 McQuarrie et al. (2008), where the detachment is at a depth of $\sim 20 \mathrm{~km}$ beneath the Corque 
435 Syncline (Fig. 8, “C”). The Tertiary basin fill is $\sim 12 \mathrm{~km}$ thick on the Altiplano with $\sim 8 \mathrm{~km}$ of

436 Paleozoic section, indicating that basement is at $\sim 20 \mathrm{~km}$ beneath this portion of the Altiplano

437 (Horton et al., 2002; Lamb and Hoke, 1997), consistent with a positive arrival observed on our

438 cross-section (Fig. 8, “C”). The detachment at the basement interface would produce a

439 discontinuity with an increase in velocity with depth, consistent with our observations and those

440 of McQuarrie, et al. (2008).

$441 \quad$ 6.3 Variations in crustal thickness

442 To better investigate whether the crust is isostatically compensated at the Moho for the

443 region as a whole, we have used a topographic model to derive the predicted Airy isostatic

444 crustal thickness to compare to our observed crustal thickness from receiver functions. Figure $9 \mathrm{~b}$

445 uses topography (GTOPO, 30 arc seconds, Lindquist, et al., 2004) low-pass filtered at $10 \mathrm{~km} \mathrm{x}$

$44610 \mathrm{~km}\left(100 \mathrm{~km}^{2}\right)$ to better match the expected spatial wavelength of isostatic compensation

447 (Molnar and England, 1990). We then use the following form of the isostasy equation to

448 calculate the Airy isostatic compensation thickness for each crustal column (Molnar and

449 England, 1990):

$$
\mathrm{T}=\mathrm{C}+\mathrm{H}+\mathrm{H} *\left[\frac{\rho_{c}}{\rho_{m}-\rho_{c}}\right]
$$

The above equation defines the crustal thickness predicted by Airy compensation (T) to

451 be the sum of the reference crustal thickness of crust (C) plus the elevation above sea level of the

452 column $(\mathrm{H})$ and the thickness of root material needed to reach compensation based on the

453 assumed densities of the crust and mantle, $\rho_{\mathrm{c}}$ and $\rho_{\mathrm{m}}$. Performing this calculation for all the

454 columns in the topographic model yields a map of predicted crustal thickness based on an initial

455 reference crustal thickness of $38 \mathrm{~km}, \rho_{\mathrm{c}}=2.8 \mathrm{~g} / \mathrm{cm}^{3}$ and $\rho_{\mathrm{m}}=3.3 \mathrm{~g} / \mathrm{cm}^{3}$ (Fig. 9b). We tested

456 reference crustal thickness values ranging from 35 to $40 \mathrm{~km}$ that all showed similar features with 
457 differences mainly in their amplitudes. We compared these predictions to the observed crustal

458 thickness we obtained by correcting our depth to Moho results (Fig. 7) to be crustal thickness

459 including topography (Fig. 9a). We subtracted the calculated crustal thickness model from our

460 observed crustal thickness to create a crustal thickness residual map (Fig. 9c). Our image shows

461 areas of undercompensated crust, where there is less crust than that needed to support elevations,

462 in blue, and areas of overcompensated crust in red, based on the simple assumptions mentioned

463 above. We do not include results in the forearc, which were not properly represented by the

464 constant density model $\left(\rho_{\mathrm{c}}=2.8 \mathrm{~g} / \mathrm{cm}^{3}\right.$ and $\left.\rho_{\mathrm{m}}=3.3 \mathrm{~g} / \mathrm{cm}^{3}\right)$ that we applied throughout the

465 region. The three largest anomalies in the residual map include an excess of $\sim 15 \mathrm{~km}$ of crust in

466 the Western Cordillera and northern Altiplano of southern Peru (anomaly F in Fig. 9c) and two

467 zones of deficit of $\sim 10 \mathrm{~km}$ of crust in parts of the Eastern Cordillera (anomalies D1, D2, and E).

468 We note that the smaller anomalies D1 and D2 are better sampled by our seismic stations than

469 anomaly E. For purposes of this paper, we will also refer to the spatially related D1 and D2

470 anomalies as a single anomaly, D.

471 Our map of depth to Moho, Figure 7, indicates that much of the Western Cordillera and

472 Altiplano regions of the CAP have Moho depths of 60-70 km (relative to sea level) similar in

473 depth to what previous authors have found farther south (Wigger et al., 1994; Swenson et al.,

474 2000; Yuan et al., 2000; Yuan et al., 2002; Beck et al., 1996; Zandt et al., 1996; Beck and Zandt,

475 2002; Wölbern et al., 2009). The crustal thickness residual map (Fig. 9c) shows the Altiplano

476 crust in southern Peru is thicker by $\sim 5-10 \mathrm{~km}$ (anomaly F) than the central Altiplano crust in

477 northwest Bolivia. The thicker crust is consistent with the results of Phillips et al., (2012) and

478 Phillips and Clayton (2014) just north of our study area. The $\sim 5-10 \mathrm{~km}$ difference would suggest

479 at least a $1 \mathrm{~km}$ change in elevation between the central and northern Altiplano, if the crust was 
480 being entirely compensated at the Moho. The surface elevation increases from $\sim 3.8 \mathrm{~km}$ in the

481 central Altiplano to $\sim 4.3 \mathrm{~km}$ in the northern Altiplano but that is accounted for in our crustal

482 thickness residual calculation. There is no indication of a larger amount of crustal shortening in

483 southern Peru. However, we cannot rule out differences in density between the crust and upper-

484 most mantle that might contribute to the difference. Preliminary results from a surface wave

485 tomography study of the same region (Ward et al., 2015) show an upper mantle high velocity

486 anomaly beneath the area of overcompensated crust suggesting an upper mantle density anomaly

487 may be partly responsible for holding down the elevations in this area.

488

Locally, parts of the Eastern Cordillera crust (east of La Paz) are thinner than predicted

489 by Airy isostasy based on smoothed topography. There are two regions of relatively high

490 smoothed elevations with crust that are $\sim 10 \mathrm{~km}$ thinner than what is predicted from our simple

491 isostatic calculation (Fig. 9c). The crust in these areas is also $\sim 10-15 \mathrm{~km}$ thinner than what we

492 observe along-strike in the Eastern Cordillera in central Bolivia, near $\sim 19-20^{\circ} \mathrm{S}$. Figure 10 shows

493 a comparison of the depth to Moho and topographic profile along two transects across the Andes,

494 one north of the Bolivian orocline (Fig. 5 B-B') and the other south of the orocline (Fig. 6 C-C').

495 Although the Eastern Cordillera is very different in width in the two profiles the average

496 maximum elevation is similar yet the crustal thickness differs by $10-15 \mathrm{~km}$. Also, the

497 topographic profiles are very different in the Interandean and Subandean zones but there is no

498 evidence for different amounts of shortening in these two regions (McQuarrie et al., 2005;

499 McQuarrie et al., 2008). The topographic difference was recognized by Masek et al. (1994) who

500 attributed the difference to differences in climate-controlled erosion and by Horton (1999) who

501 suggested that increased erosion rates in the north influenced the kinematics of thrust belt 
502 development. An additional difference is that the southern profile passes through the Los Frailes

503 Volcanic Field, a Late Cenozoic ignimbrite center (Baker, 1981).

The two regions of thinned crust in Fig. 9c have been designated anomalies D (1 and 2)

505 and E. Both regions of thinner crust are spatially small and isolated; anomaly D, beneath the 506 northern Eastern Cordillera is $\sim 150 \mathrm{~km}$ by $50 \mathrm{~km}$, while the thin crust in anomaly E extends

$507 \sim 300 \mathrm{~km}$ along-the strike of the Eastern Cordillera and is roughly $\sim 100 \mathrm{~km}$ wide. The western 508 edges of the thin crust in the Eastern Cordillera correlate well with Triassic and Miocene 509 plutonic bodies, but the mapped surface area of those plutons is an order of magnitude less than 510 the area over which thinner crust is observed.

$511 \quad$ 6.4 Tectonic implications

512 There are a number of possible mechanisms for modifying the crustal thickness, 513 including climate controlled erosion, lower crustal flow, and lithospheric delamination. In the 514 following paragraphs we briefly discuss how each of these mechanisms may fit with our 515 observations of isostatic compensation.

516 Enhanced erosion could explain crustal thinning if there is no shortening in the same 517 region. This would lead to a thinning of the crust and slightly lower average elevations (Molnar 518 and England, 1990). Furthermore, if the erosion occurs non-uniformly (i.e. due to the incision of 519 deep valleys and the exhumation of steep peaks), the resulting high relief landscape, after 520 isostatic adjustment, will have a slightly lower average elevation but the Moho will move up as 521 much as the tallest peaks are exhumed. This process could explain the existence of the high relief 522 Cordillera Real with peaks as high as $6 \mathrm{~km}$, in an area of relatively thin crust (Fig. 5). Although our crustal thickness residual map suggests that areas with thin crust are

524 undercompensated, this result is based on a low-pass filtering of the topography of the entire 
525 study region. To get a more accurate sense of the isostasy relationships in the Eastern Cordillera, 526 we selected an area bounded by a rectangle that encloses the Eastern Cordillera between $\sim 15^{\circ} \mathrm{S}$ 527 and $18^{\circ} \mathrm{S}$ (yellow box in Fig. 9c). The mean elevation in this area is 3.1 kilometers, which would 528 indicate a predicted isostatic Moho depth of $55 \mathrm{~km}$. From Figure 1 it is clear that there is a steep 529 topographic gradient in this area, so we divided the rectangle lengthwise into a southwestern half 530 and a northeastern half and repeated the isostasy calculation for each. The western half has a 531 mean elevation of $3.9 \mathrm{~km}$ with a predicted isostatic Moho depth of $60 \mathrm{~km}$ and the eastern half 532 has a mean elevation of $2.2 \mathrm{~km}$ and a predicted Moho depth of $50 \mathrm{~km}$. Comparing these 533 predicted depths with the Moho depth profile along our dense line in Fig. 10 we observe the EC 534 appears to be, on average, near isostatic equilibrium with an average Moho depth of $55 \mathrm{~km}$. But 535 in detail, the western half of the EC appears slightly undercompensated and the eastern half is 536 slightly overcompensated. This more detailed result is generally consistent with our previous 537 larger scale result in Fig. 9c, but the amplitudes of under- and overcompensation, $\sim 5 \mathrm{~km}$, are 538 better constrained in Fig. 10. In Fig. 9c, we overlay contours of average annual precipitation 539 from the Tropical Rainfall Measuring Mission (TRMM), using data from the years 1998 through 540 the present (Huffman and Bolvin, 2015). The anomalously thin crust beneath parts of the Eastern 541 Cordillera (anomalies D and E) is located slightly southwest (or upstream) of the locations of 542 maximum annual precipitation, as expected if orographic precipitation is driving rock uplift 543 (Norton and Schlunegger, 2011). Of course, this relationship would only hold for as long as the 544 current pattern of orographic precipitation has existed. Various studies of this question generally 545 conclude the current pattern was established in the Late Miocene, 10-15 Ma (Gillis et al., 2006; 546 Mosolf et al., 2010; Barnes et al., 2012). The northern region of anomalous thin crust (Anomalies 547 D1 and D2) has peaks up to $6 \mathrm{~km}$ that correspond to Triassic and Miocene plutons exposed at the 
548 surface (Gillis et al., 2006). Gillis et al. (2006) used ${ }^{40} \mathrm{Ar} /{ }^{39} \mathrm{Ar}$ fission track thermochronology 549 and $\mathrm{U}-\mathrm{Pb}$ geochronology in the Eastern Cordillera to estimate that $\sim 7.5 \mathrm{~km}$ of exhumation 550 occurred during the Eocene-Oligocene with concomitant crustal shortening and $\sim 3-5 \mathrm{~km}$ of rapid 551 exhumation occurred during the Miocene. At face value, this suggests the $\sim 5 \mathrm{~km}$ thinning in the 552 western EC may be attributable to climate driven erosion.

553 Crustal flow may also be an important process in explaining our isostatic compensation 554 model of the central Andean crust (Husson and Sempere, 2003; Kay and Coira, 2009).

555 Eichelberger, et al. (2015), present evidence that crustal flow has had a significant influence on 556 the evolution of crustal thickness in this region. Eichelberger, et al. (2015) used estimates of the 557 crustal shortening rates to predict the crustal thickness and compared their results with our 558 present-day observations of Moho depth. Their 3D volumetric crustal models are sensitive to the 559 shortening rate, constrained by structural reconstructions done across the CAP and the initial 560 cratonic thickness, which is poorly constrained. They suggest that with either initial crustal 561 thicknesses of $35 \mathrm{~km}$ or $40 \mathrm{~km}$ some amount of lithospheric removal as well as some lower 562 crustal flow likely occurred over the last $25 \mathrm{Ma}$ to account for the modern distribution of crustal 563 thickness that we observe (Eichelberger et al., 2015). Lower crustal flow could provide a 564 mechanism to redistribute crust from the Eastern Cordillera near La Paz (Fig. 9 anomalies D1 565 and D2 with thinner than expected crust) to the northern Altiplano (Figure 9 anomaly F) where 566 there is thicker than expected crust.

567 Lithospheric removal is an alternative mechanism that could lead to areas that are not in 568 isostatic equilibrium. Numerous studies have concluded that lithospheric removal has occurred 569 throughout much of the Andes, and may have been an important factor in the uplift of the CAP, 570 although studies disagree as to the size and timing of the material removed (Kay and Kay, 1993; 
571 Yuan et al., 2000; Yuan et al., 2002; Beck and Zandt, 2002; Molnar and Garzione, 2007; Beck et 572 al., 2015). In contrast to the region near La Paz, the Eastern Cordillera near $19-20^{\circ} \mathrm{S}$ has thick 573 crust $(\sim 65-70 \mathrm{~km})$ that is slightly thicker than the Altiplano and appears to be near isostatic 574 equilibrium at the Moho (Fig. 6b). We note that there is also less erosion or exhumation in this 575 region as evidenced by the San Juan Del Oro surface, a regionally extensive undeformed 576 geomorphic surface that is dated as $\sim 10 \mathrm{Ma}$ (Gubbels et al., 1993). The Eastern Cordillera 577 landforms farther south are only slightly modified and the topographic relief of the eastern CAP 578 margin is more gradual and consistent with less erosion (Masek et al., 1994). Still, the difference 579 in Moho depths beneath the eastern EC and adjacent Interandean Zone across the two transects is 580 dramatic (Fig. 10). There is strong geophysical and geochemical evidence for late Cenozoic 581 lithospheric delamination beneath the Los Frailes Volcanic Field (Myers et al., 1998; Beck et al., 582 2002; Kato et al., 2014). Both numerical modeling of delamination of lithosphere with weak 583 lower crust (Krystopowicz and Currie, 2013) and seismological imaging of young delamination 584 beneath the Puna plateau (Beck et al., 2015) show the post-delamination lithospheric 585 characteristics include high elevations, thick felsic crust, and thin lithosphere. Thus, south of the 586 orocline at $\sim 20^{\circ} \mathrm{S}$, the much thicker and isostatically compensated crust can be attributed to a 587 combination of the absence of erosional exhumation and the occurrence of lithospheric 588 delamination. The lack of a crustal root and abundant backarc volcanism in the EC between $\sim 18^{\circ}$ 589 to $14^{\circ} \mathrm{S}$ suggests that if late Miocene delamination has occurred in the Altiplano as suggested by 590 Garzione et al. (2006) it has not progressed into the Eastern Cordillera at these latitudes. Further 591 validation of this preliminary conclusion regarding delamination awaits ongoing studies of the 592 upper mantle structure in this region. 
600

601

602

603

604

605

606

607

608

609

610

611

612

613

614

615

616

\section{Conclusions}

We have used our new receiver function results combined with previous work to investigate the crustal structure in the Bolivian orocline region of the Central Andes, in southern Peru and northern Bolivia. Our principal results are listed below:

1. We determined a well-resolved depth to Moho map (relative to sea level) that shows values that range from $40 \mathrm{~km}$ to $75 \mathrm{~km}$. In general, we observe thick, $65-75 \mathrm{~km}$ crust underneath the Western Cordillera and Altiplano, and the thinnest crust, $40 \mathrm{~km}$, beneath the Subandean zone. In the Eastern Cordillera, our results show variable thickness crust ranging from $50-70 \mathrm{~km}$ depending on the location.

2. We identified the top of a low velocity zone at $\sim 15 \mathrm{~km}$ beneath the Western Cordillera, corresponding to a low-velocity zone previously identified through an ambient noise study (Ward, et al., 2013).

3. Our results show an increase in velocity under the Eastern Cordillera and Subandean zone along B-B' that corresponds with the basal décollement in the balanced crosssection from McQuarrie, et al., (2008). We interpret an increase in velocity beneath the Altiplano at $20 \mathrm{~km}$ as the top of the basement.

4. We found two areas in the Eastern Cordillera with thinner than expected crust based on local Airy isostasy. These areas are adjacent to locations of high precipitation and erosion suggesting that climate induced exhumation may have contributed to thinning the crust, in addition to the possibility that lower crust was redistributed through the localized effects of crustal flow.

5. Our results confirm earlier results of thick crust near isostatic equilibrium in the eastern Cordillera near latitude $20^{\circ} \mathrm{S}$ where the Los Frailes volcanic field is located. We 
conclude the thicker crust here is due to a combination of much lower rates of erosion and the occurrence of late Cenozoic delamination at this latitude.

619

620

\section{Acknowledgements}

The authors would like to recognize the National Science Foundation, NSF, for their

622 support through grant EAR-0907880 (CAUGHT) and EAR-1415914. We thank Nadine

623 McQuarrie and Nathan Eichelberger for their comments that improved the manuscript. We

624 would like to thank personnel from the Incorporated Research Institutions for Seismology (IRIS)

625 PASSCAL division, the University of Arizona, University of North Carolina at Chapel Hill, Yale

626 University, the Instituto Geofísico del Perú and the workers and staff from the San Calixto

627 Observatorio in Bolivia for their invaluable field and logistic assistance. IRIS personnel were

628 also critical in preparing and archiving the data for publication through their Data Management

629 System (DMS). The facilities of the IRIS Consortium are supported by the National Science

630 Foundation under Cooperative Agreement EAR-1063471, the NSF Office of Polar Programs and 631 the DOE National Nuclear Security Administration. The Global Seismographic Network (GSN)

632 is a cooperative scientific facility operated jointly by the Incorporated Research Institutions for

633 Seismology (IRIS), the United States Geological Survey (USGS), and the National Science

634 Foundation (NSF). The authors would also like to thank Rob Clayton and Paul Davis for 635 providing PeruSE data. 


\section{References}

Allmendinger, R.W., \& Gubbels T., 1996. Pure and simple shear plateau uplift, Altiplano-Puna, Argentina and Bolivia. Tectonophysics, 259, 1-13, doi:10.1016/0040-1951(96)00024-8.

Allmendinger, R. W., Jordan, T. E., Kay, S. M. \& Isacks, B. L., 1997. The evolution of the Altiplano-Puna Plateau of the Central Andes. Annu. Rev. Earth Planet. Sci., 25, 139-174, doi:10.1146/annurev.earth.25.1.139.

Ammon, C. J., Randall G. E., \& Zandt, G, 1990. On the Nonuniqueness of Receiver Function Inversions. J. Geophys. Res., 95, 15,303-15,318, doi:10.1029/JB095iB10p15303.

Ammon, C. J., 1991. The isolation of receiver effects from teleseismic P waveforms. Bull. Seismol. Soc. Am., 81, 2504-2510.

ANCORP Working Group, 2003. Seismic imaging of a convergent continental margin and plateau in the central Andes (Andean Continental Research Project 1996 (ANCORP'96)), J. Geophys. Res., 108, 2328, doi:10.1029/2002JB001771.

Assumpção, M., Feng, M., Tassara, A., Julià J., 2013. Models of crustal thickness for South America from seismic refraction, receiver functions and surface wave tomography, Tectonophysics, 609, 82-96, doi: 0.1016/j.tecto.2012.11.014.

Baby, P., Rochat, P., Mascle, G., \& Herail, G., 1997. Neogene shortening contribution to crustal thickening in the back arc of the Central Andes, Geology, 25, 883-886, doi:10.1130/0091-7613(1997)025<0883:NSCTCT>2.3.CO;2.

Baker, M.C.W., 1981. The nature and distribution of upper Cenozoic ignimbrite centres in the Central Andes, J. Volcanol. Geotherm. Res., 11, 293-315, doi:10.1016/0377-0273(81)90028-7.

Barnes, J.B., Ehlers, T.A., Insel, N., McQuarrie, N., Poulsen, C.J., 2012. Linking orography, climate, and exhumation across the central Andes, Geology, 40, 1135-1138, doi: 10.1130/G33229.1,

Beck, S.L., Zandt, G., Myers, S.C., Wallace, T.C., Silver, P.G. \& Drake, L., 1996. Crustalthickness variations in the central Andes, Geology, 24, 407-410, doi:10.1130/00917613(1996)024<0407:CTVITC $>2.3 . C O ; 2$.

Beck, S.L. \& Zandt, G., 2002. The nature of orogenic crust in the central Andes, J. Geophys. Res.-Solid Earth, 107, 2230-2247, doi:10.1029/2000JB000124.

Beck, S.L., Zandt, G., Ward, K.M., Scire, A., 2015. Multiple styles and scales of lithospheric foundering beneath the Puna Plateau, central Andes, Geo. Soc. Mem., 212, 43-60, doi:10.1130/2015.1212(03).

Cassidy, J. F., 1992. Numerical experiments in broadband receiver function analysis, Bull. Seismol. Soc. Am., 82, 1453-1474.

Chmielowski, J., Zandt, G. \& Haberland, C., 1999. The Central Andean Altiplano-Puna Magma body, Geophys. Res. Lett., 26, 783-786, doi:10.1029/1999GL900078.

Chulick, G.S., Detweiler, S. \& Mooney W.D., 2013. Seismic structure of the crust and uppermost mantle of South America and surrounding oceanic basins, J. South Am. Earth. Sci., 42, 260-276, doi:10.1016/j.jsames.2012.06.002. 
DeCelles, P. G. and Horton, B. K., 2003. Early to middle Tertiary foreland basin development and the history of Andean crustal shortening in Bolivia, Geol. Soc. Am. Bull., 115, 58-77, doi:10.1130/0016-7606.

DeCelles, P. G., Carrapa, B., Horton, B. K. \& Gehrels, G. E., 2011. Cenozoic foreland basin system in the central Andes of northwestern Argentina: Implications for Andean geodynamics and modes of deformation, Tectonics, 30, 1-30, doi:10.1029/2011TC002948.

DeCelles, P. G., Ducea, M. N., Kapp, P. \& Zandt, G., 2009. Cyclicity in Cordilleran orogenic systems, Nat. Geosci., 2, 251-257, doi:10.1038/ngeo469.

Dorbath, C., Granet, M., Poupinet, G. \& Martinez, C., 1993. A teleseismic Study of the Altiplano and the Eastern Cordillera in Northern Bolivia: New Constraints on a Lithospheric Model, J. Geophys. Res., 98, 9825-9844, doi:10.1029/92JB02406.

Dorbath, L., Dorbath, C., Jimenez, E., \& Rivera, L., 1991. Seismicity and tectonic deformation in the Eastern Cordillera and the sub-Andean zone of central Peru, J. South Am. Earth Sci., 4, 13-24, doi:10.1016/0895-9811(91)90015-D.

Dorbath, C., \& Granet, M., 1996. Local earthquake tomography of the Altiplano and the Eastern Cordillera of northern Bolivia, Tectonophysics, 259, 117-136, doi:10.1016/00401951(95)00052-6.

Dueker, K. \& Sheehan, A., 1997. Mantle discontinuity structure from midpoint stacks of converted P to S waves across the Yellowstone hotspot track. J. Geophys. Res., 102, 8313-8327, doi:10.1029/96JB03857.

Eichelberger, N., \& McQuarrie, N., 2015. Kinematic reconstruction of the Bolivian orocline, Geosphere, 11(2), 445-462, doi:10.1130/GES01064.1.

Eichelberger, N., McQuarrie, N., Ryan, J., Karimi, B., Beck, S., \& Zandt, G., 2015. Evolution of crustal thickening in the central Andes, Bolivia, Earth Planet. Sci. Lett., 426, 191-203, doi:10.1016/j.eps1.2015.06.035

Elger, K., Oncken, O. \& Glodny, J., 2005. Plateau-style accumulation of deformation: Southern Altiplano, Tectonics, 24, 1-19, doi:10.1029/2004TC001675.

Feng, M, van der Lee, S., Assumpção, M., 2007. Upper mantle structure of South America from join inversion of waveforms and fundamental mode group velocities of Rayleigh waves. J. Geophys. Res., 112, 1-16, doi:10.1029/2006JB004449.

Frassetto, A., Zandt, G., Gilbert, H., Owens, T. J., Jones, C. J., 2010. Improved imaging with phase-weighted common conversion point stacks of receiver functions. Geophys. J. Int., 182, 368-374, doi: 10.1111/j.1365-246X.2010.04617.x.

Frassetto, A., \& Thybo, H., 2013. Receiver function analysis of the crust and upper mantle in Fennoscandia - isostatic implications, Earth Planet. Sci. Lett., 381, 234-246, doi: 10.1016/j.eps1.2013.07.001.b

Garzione, C. N., Molnar, P., Libarkin, J. C., \& MacFadden, B. J., 2006. Rapid late Miocene rise of the Bolivian Altiplano: Evidence for removal of mantle lithosphere, Earth Planet. Sci. Lett., 241, 543-556, doi:10.1016/j.eps1.2005.11.026.

Garzione, C. N., Hoke, G. D., Libarkin, J. C., Withers, S., MacFadden, B., Eiler, J., Ghosh, P., Mulch, A., 2008. Rise of the Andes, Science, 320, 1304-1307, doi: 10.1126/science. 1148615 . 
Giese, P., Scheuber, E., Schilling, F., Schmitz, M. \& Wigger, P., 1999. Crustal thickening processes in the central Andes and the different natures of the Moho-discontinuity, $J$. South Am. Earth Sci., 12, 201-220, doi: 10.1016/S0895-9811(99)00014-0.

Gillis, R. J., Horton, B. K. \& Grove, M., 2006. Thermochronology, geochronology, and upper crustal structure of the Cordillera Real: Implications for Cenozoic exhumation of the central Andean plateau, Tectonics, 25, 1-22, doi:10.1029/2005TC001887.

Gotberg, N., McQuarrie, N., \& Caillaux, V. C., 2010. Comparison of crustal thickening budget and shortening estimates in southern Peru (12-14 $\left.{ }^{\circ} \mathrm{S}\right)$ : Implication for mass balance and rotations in the "Bolivian orocline," Geol. Soc. Am. Bull., 122, 727-742, doi:10.1130/B26477.1

Graeber, F. M. \& Asch, G., 1999. Three-dimensional models of P wave velocity and P-to-S velocity ratio in the southern central Andes by simultaneous inversion of local earthquake data, J. Geophys. Res., 104, 20,237-20,256, doi:10.1029/1999JB900037.

Hayes, G. P., Wald, D. J. \& Johnson, R. L., 2012. Slab1.0: a three-dimensional model of global subduction zone geometries, J. Geophys. Res.-Sol Ea, 117, doi:10.1029/2011JB008524.

Hoke, G.D., \& Garzione, C. N., 2008. Paleosurfaces, paleoelevation, and the mechanisms for the late Miocene topographic development of the Altiplano plateau, Earth Planet. Sci. Lett., 271, 192-201, doi:10.1016/j.eps1.2008.04.008.

Horton, B.K. 1999. Erosional control on the geometry and kinematics of thrust belt development in the central Andes, Tectonics, 18, 1292-1304, doi:10.1029/1999TC900051.

Huffman, G.J. \& Bolvin, D.T. 2012, last updated 2015: 3B42.V7.TMPA. NASA/GSFC, Greenbelt, MD, USA, NASA Goddard Earth Sciences Data and Information Services Center (GES DISC). Accessed 05/16/14 at http://pmm.nasa.gov/dataaccess/downloads/trmm.

Husson, L. \& Sempere, T., 2003. Thickening the Altiplano crust by gravity-driven crustal channel flow, Geophys. Res. Lett, 30, 1243, doi:10.1029/2002GL016877.

Insel, N., Poulsen, C.J., Ehlers, T., Sturm, C., 2012. Response of meteoric $\delta 180$ to surface uplift-Implications for Cenozoic Andean Plateau growth, Earth Planet. Sci. Lett., 317-318, 262-272, doi:10.1016/j.eps1.2011.11.039.

Isacks, B. L., 1988. Uplift of the Central Andean Plateau and bending of the Bolivian Orocline, J. Geophys. Res.-Solid Earth, 93, 3211-3231, doi:10.1029/JB093iB04p03211.

Kato, J.J., Kay, S.M., Coira, B.L., Jicha, B.R., Harris, C., Caffe, P.J., Jimenez, N., 2014. Evolution and geochemistry of the Neogene Los Frailes ignimbrite complex on the Bolivian Altiplano Plateau, XIX Congreso Geológico Argentino, Junio 2014, Córdoba, in Volcanismo De Los Andes - Volcanismo Silíceo.

Kay, S.M., and Coira, B.L., 2009, Shallowing and steepening subduction zones, continental lithospheric loss, magmatism, and crustal fl ow under the central Andean Altiplano-Puna Plateau, in Kay, S.M., Ramos, V.A., and Dickinson, W.R., eds., Backbone of the Americas: Shallow Subduction, Plateau Uplift, and Ridge and Terrane Collision: Geo. Soc. Mem. 204, p. 229-260, doi: 10.1130/2009.1204(11).

Kay, R. W. \& Kay, S. M., 1993. Delamination and delamination magmatism, Tectonophysics, 219, 177-189, doi:10.1016/0040-1951(93)90295-U. 
Kley, J., 1996. Transition from basement-involved to thin-skinned thrusting in the Cordillera Oriental of southern Bolivia, Tectonics, 15, 763-775, doi: 10.1029/95TC03868.

Kley, J., \& Monaldy, C., 1998. Tectonic shortening and crustal thickness in the Central Andes: How good is the correlation? Geology, 26, 723-726, doi:10.1130/0091-7613(1998) 026<0723:TSACTI $>2.3 . \mathrm{CO} ; 2$.

Kley, J., 1999. Geologic and geometric constraints on a kinematic model of the Bolivian orocline. J. South Am. Earth Sci., 12, 221.235, doi: 10.1016/S0895-9811(99)00015-2.

Krystopowicz, N. J. \& Currie, C. A., 2013. Crustal eclogitization and lithosphere delamination, Earth Planet. Sci. Lett., 361, 195-207, doi:10.1016/j.eps1.2012.09.056.

Lamb, S., 2011. Did shortening in thick crust cause rapid Late Cenozoic uplift in the northern Bolivian Andes? J. Geol. Soc. Lond., 168, 1079-1092, doi:10.1144/0016-76492011-008.

Leier, A., McQuarrie, N., Garzione, C., Eiler, J., 2013. Stable isotope evidence for multiple pulses of rapid surface uplift in the Central Andes, Bolivia, Earth Planet. Sci. Lett., 371372, 49-58, doi:10.1016/j.eps1.2013.04.025.

Ligorría, J. P., \& Ammon, C. J., 1999. Iterative Deconvolution and Receiver-Function Estimation. Bull. Seismol. Soc. Am., 89, 1395-1400.

Lindquist, K. G., Engle, K., Stahlke, D. \& Price, E., 2004. Global Topography and Bathymetry Grid Improves Research Efforts, Eos Trans. AGU, 85(19), 186.

Lloyd, S., van der Lee, S., Sand França, G., Assumpção, M., Feng, M., 2010. Moho map of South America from receiver functions and surface waves, J. Geophys. Res., 115, 1-12, doi:10.1029/2009JB006829.

Masek, J.G., Isacks, B.L., Gubbels, T.L. \& Fielding, E.J., 1994. Erosion and tectonics at the margins of continental plateaus, J. Geophys. Res., 99, 13,941-13,956, doi:10.1029/94JB00461.

McGlashan, N., Brown, L., \& Kay, S, 2008. Crustal thickness in the central Andes from teleseismically recorded depth phase precursors, Geophys. J. Int., 175, 1013-1022, doi:10.1111/j.1365-246X.2008.03897.x

McQuarrie, N., DeCelles, P., 2001. Geometry and structural evolution of the central Andean backthrust belt, Bolivia, Tectonics, 20, doi: 10.1029/2000TC001232.

McQuarrie, N., Horton, B. K., Zandt, G., Beck, S. \& DeCelles, P. G., 2005. Lithospheric evolution of the Andean fold-thrust belt, Bolivia, and the origin of the central Andean plateau, Tectonophysics, 399, 15-37, doi:10.1016/j.tecto.2004.12.013.

McQuarrie, N., Barnes, J. B. \& Ehlers, T. A., 2008. Geometric, kinematic, and erosional history of the Central Andean Plateau, Bolivia (15-17 degrees S), Tectonics, 27, doi:10.1029/2006TC002054.

Molnar, P. \& England, P., 1990. Late Cenozoic uplift of mountain ranges and global climate change: chicken or egg? Nature, 346, 29-34, doi: 10.1038/346029a0.

Molnar, P. \& Garzione, C. N., 2007. Bounds on the viscosity coefficient of continental lithosphere from removal of mantle lithosphere beneath the Altiplano and Eastern Cordillera, Tectonics, 26, 1-9, doi:10.1029/2006TC001964.

Mosolf, J. G., Horton, B. K., Heizler, M. T., Matos, R., 2010. Unroofing the core of the central Andean fold-thrust belt during focused late Miocene exhumation: evidence from the 
Tipuani-Mapiri wedge-top basin, Bolivia, Basin Res., 23, 346-360, doi:10.1111/j.13652117.2010.00491.x.

Myers, S., Beck, S., Zandt, G. \& Wallace, T., 1998. Lithospheric-scale structure across the Bolivian Andes from tomographic images of velocity and attenuation for $P$ and $S$ waves, J. Geophys. Res., 103, 21,233-21,252, doi:10.1029/98JB00956.

Norton, K. \& Schlunegger, F., 2011. Migrating deformation in the Central Andes from enhanced orographic rainfall, Nat. Commun., 2:584, 1-7, doi: 10.1038/ncomms 1590.

Phillips, K., Clayton, R. W., Davis, P., Tavera, H., Guy, R., Skinner, S., Stubailo, I., Audin, L., Aguilar, V., 2012. Structure of the subduction system in southern Peru from seismic array data, J. Geophys. Res.-Solid Earth, 117, B11306, doi:10.1029/2012JB009540.

Phillips, K., Clayton, R. W., 2014. Structure of the subduction transition region from seismic array data in southern Peru, Geophys. J. Int., 196, 1889-1905, doi: 10.1093/gji/ggt504

Poulsen, C.J., Ehlers, T., Insel, N., 2010. Onset of convective rainfall during gradual late Miocene rise of the central Andes, Science, 328, 490-493.,doi: 10.1126/science.1185078.

Schmitz, M. \& Kley, J., 1997. The Geometry of the Central Andean Backarc Crust: Joint Interpretation of Cross-section Balancing and Seismic Refraction Data, J. South Am. Earth Sci., 10, 99-100, doi:10.1016/S0895-9811(97)00009-6.

Sheehan, A. F., Shearer, P. M., Gilbert, H. J., \& Dueker, K. G., 2000. Seismic migration processing of P-SV converted phases for mantle discontinuity structure beneath the Snake River Plain, western United States, J. Geophys. Res., 105, 19055-19065, doi:10.1029/2000JB900112.

Storchak, D. A., Giacomo, D. D., Bondár, I., Engdahl, E. R., Harris, J., Lee, W. H. K., Villaseñor, A., Bormann, P., 2013. Public Release of the ISC-GEM Global Instrumental Earthquake Catalogue (1900-2009), Seism. Res. Lett., 84, 5, 810-815, doi: $10.1785 / 0220130034$.

Swenson, J., Beck, S. \& Zandt, G., 2000. Crustal structure of the Altiplano from broadband regional waveform modeling: Implications for the composition of thick continental crust, J. Geophys. Res., 105, 607 - 621, doi:10.1029/1999JB900327.

Tassara, A., Götze, H.-J., Schmidt, S. \& Hackney, R., 2006. Three-dimensional density model of the Nazca plate and the Andean continental margin, J. Geophys. Res., 111, B09404, doi:10.1029/2005JB003976.

van der Meijde, M., Julià, J. and M. Assumpção, M., 2013. Gravity derived Moho for South America, Tectonophysics, 609, 456-467, doi: 10.1016/j.tecto.2013.03.023.

Wada, I., K. Wang, J. He, and R. D. Hyndman (2008), Weakening of the subduction interface and its effects on surface heat flow, slab dehydration, and mantle wedge serpentinization, J. Geophys. Res., 113, B04402, doi:10.1029/2007JB005190.

Ward, K. M., Porter, R. C., Zandt, G., Beck, S., Wagner, L., Minaya, E. \& Tavera, H., 2013. Ambient noise tomography across the Central Andes, Geophys. J. Int., 194, 1559-1573, doi:10.1093/gji/ggt166.

Whipple, K. X., \& Gasparini, N.M., 2014. Tectonic control of topography, rainfall patterns, and erosion during rapid post-12 Ma uplift of the Bolivian Andes, Lithosphere, 6, 251-268, doi: $10.1130 / \mathrm{L} 325.1$. 
Whitcomb, J. H., Garmany, J. D., Anderson, D. L., 1972. Earthquake Prediction: Variation of Seismic Velocities before the San Francisco Earthquake, Science, 180, 632-635, doi: 10.1126/science. 180.4086 .632 .

Wigger, P. J., et al., 1994. Variation in the Crustal Structure of the Southern Central Andes Deduced from Seismic Refraction Investigations, in Tectonics of the Southern Central Andes, pp.23-48, eds Reutter, K.-J., Scheuber, E. \& Wigger, P.J., Springer-Verlag, Berlin, doi: 10.1007/978-3-642-77353-2_2.

Wölbern, I., Heit, B., Yuan, X., Asch, G., Kind, R., Viramonte, J., Tawackoli, S. \& Wilke, H., 2009. Receiver function images from the Moho and the slab beneath the Altiplano and Puna plateaus in the Central Andes, Geophys. J. Int., 177, 296-308, doi: 10.1111/j.1365246X.2008.04075.x.

Yuan, X. et al., 2000. Subduction and collision processes in the Central Andes constrained by converted seismic phases, Nature, 408, 958-961, doi: 10.1038/35050073.

Yuan, X., Sobolev, S. V. \& Kind, R., 2002. Moho topography in the central Andes and its geodynamic implications, Earth planet. Sci. Lett., 199, 389-402, doi: 10.1016/S0012821X(02)00589-7.

Zandt, G., Beck, S., Ruppert, S., Ammon, C., Rock, D., Minaya, R., Wallace, T. \& Silver, P., 1996. Anomalous crust of the Bolivian Altiplano, central Andes: Constraints from broadband regional seismic waveforms, Geophys. Res. Lett., 23, 1159-1162, doi:10.1029/96GL00967.

Zandt, G., Leidig, M., Chmielowski, J., Baumont, D. \& Yuan, X. H., 2003. Seismic detection and characterization of the Altiplano-Puna Magma Body, central Andes, Pure Appl. Geophys., 160, 789-807, doi: 10.1007/PL00012557.

Zandt, G., Gilbert, H., Owens, T. J., Ducea, M., Saleeby, J. \& Jones., C. H., 2004. Active foundering of a continental arc root beneath the southern Sierra Nevada in California, Nature, 431, 41-46, doi: 10.1038/nature02847.

Zhu, L., \& Kanamori, H., 2000. Moho depth variation in southern California from teleseismic receiver functions, J. Geophys. Res., 105, 2969-2980, doi:10.1029/1999JB900322. 


\begin{tabular}{|l|c|c|c|}
\hline \multicolumn{1}{|c|}{ Array Name } & $\begin{array}{c}\text { Number of } \\
\text { Stations Used }\end{array}$ & Time Period & Reference \\
\hline CAUGHT (doi:10.7914/SN/ZG_2010) & 51 & $10 / 2010-08 / 2012$ & 1 \\
\hline BANJO-SEDA & 23 & $05 / 1994-08 / 1995$ & 1 \\
\hline $\begin{array}{l}\text { Global Telemetered Seismograph Network } \\
\text { (LPAZ, doi:10.7914/SN/IU) }\end{array}$ & 1 & $08 / 1993-$ present & 2 \\
\hline Observatorio San Calixto & 6 & $02 / 2012$-present & 3 \\
\hline Chilean National Seismic Network (GO01) & 1 & $08 / 2011-$ present & 4 \\
\hline Plate Boundary Project; GFZ portion of IPOC & 6 & $12 / 2006-$ present & 4 \\
\hline
\end{tabular}

Table 1: Arrays, number of stations, and time period of the deployment for the stations used to create and migrate the receiver functions presented in this study. References are as follows:

\section{1) IRIS DMS}

IRIS Data Management System, Seattle, Washington

The facilities of the IRIS Data Management System were used for access to waveform, metadata or products required in this study. The IRIS DMS is funded through the National Science Foundation Cooperative Agreement EAR-1063471. Some IRIS activities are supported by the National Science Foundation EarthScope Program under Cooperative Agreements EAR-0733069, EAR-1261681.

\section{2) GSN / IRIS Global Seismographic Network}

(including H2, IC, II, IU, MS)

Global Seismographic Network is a cooperative scientific facility operated jointly by the Incorporated Research Institutions for Seismology (IRIS), the United States Geological Survey (USGS), and the National Science Foundation (NSF). http://www.iris.edu/hq/programs/gsn

\section{3) Observatorio of San Calixto}

The San Calixto Observatory is a private non-profit seismic observatory.

\section{4) GE / (GEOFON)}

GFZ Potsdam, Germany

The GEOFON network is funded and operated by GFZ Potsdam, Germany, in co-operation with almost 50 institutions worldwide.

http://geofon.gfz-potsdam.de/geofon/ 


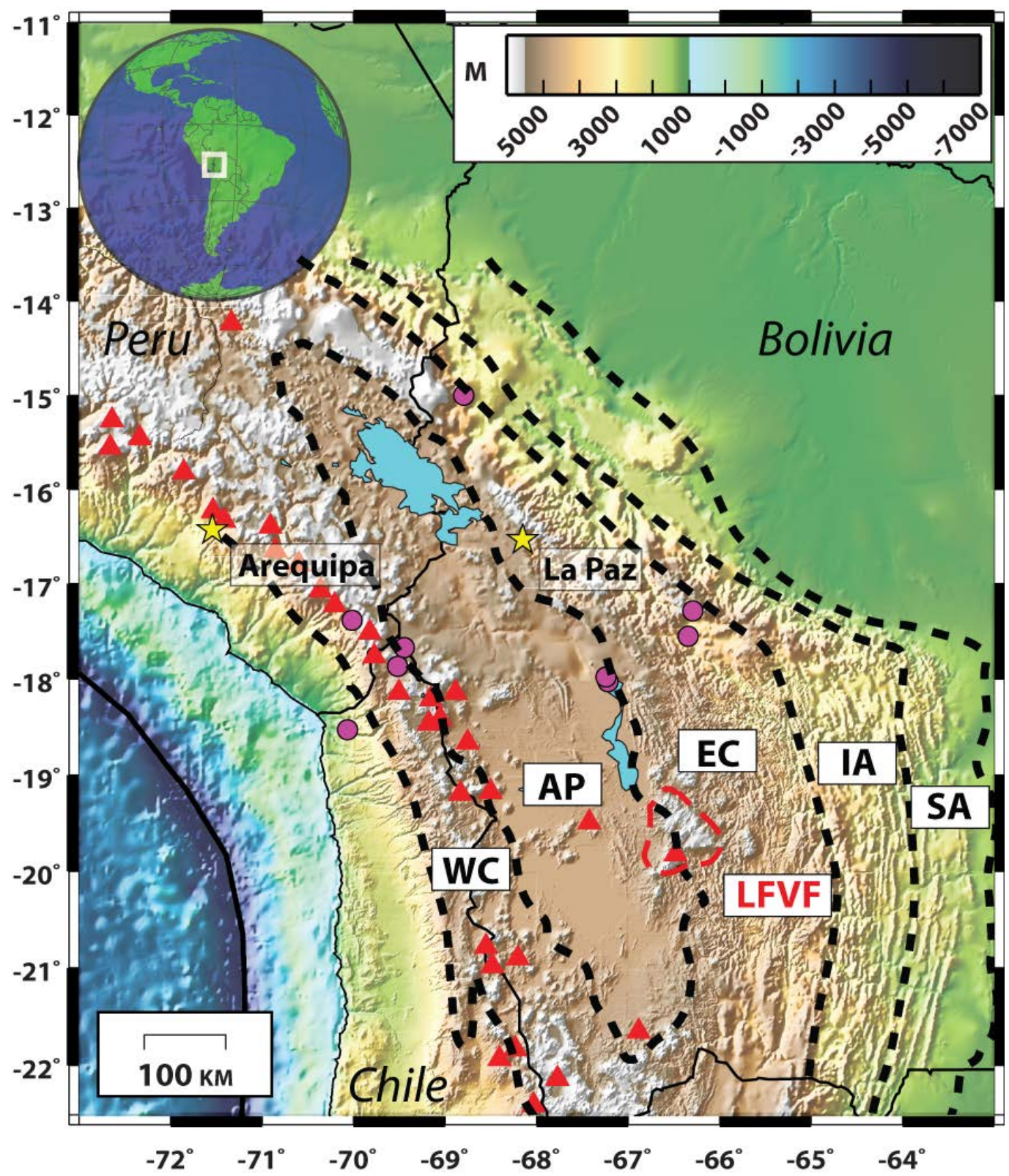

Figure 1: Topographic map of the central Andes and geomorphic province boundaries for the Western Cordillera (WC), Altiplano (AP), Eastern Cordillera (EC), Interandean (IA), and Subandean Zone (SA) modified from McQuarrie et al., (2008) and Mosolf et al., (2010); Holocene volcanoes shown as red triangles. The Los Frailes Volcanic Field (LFVF) is outlined in dashed red. Yellow stars show the location of major population centers, and purple circles show the location of local events used in the Wadati diagram (Fig. 4). 
a)

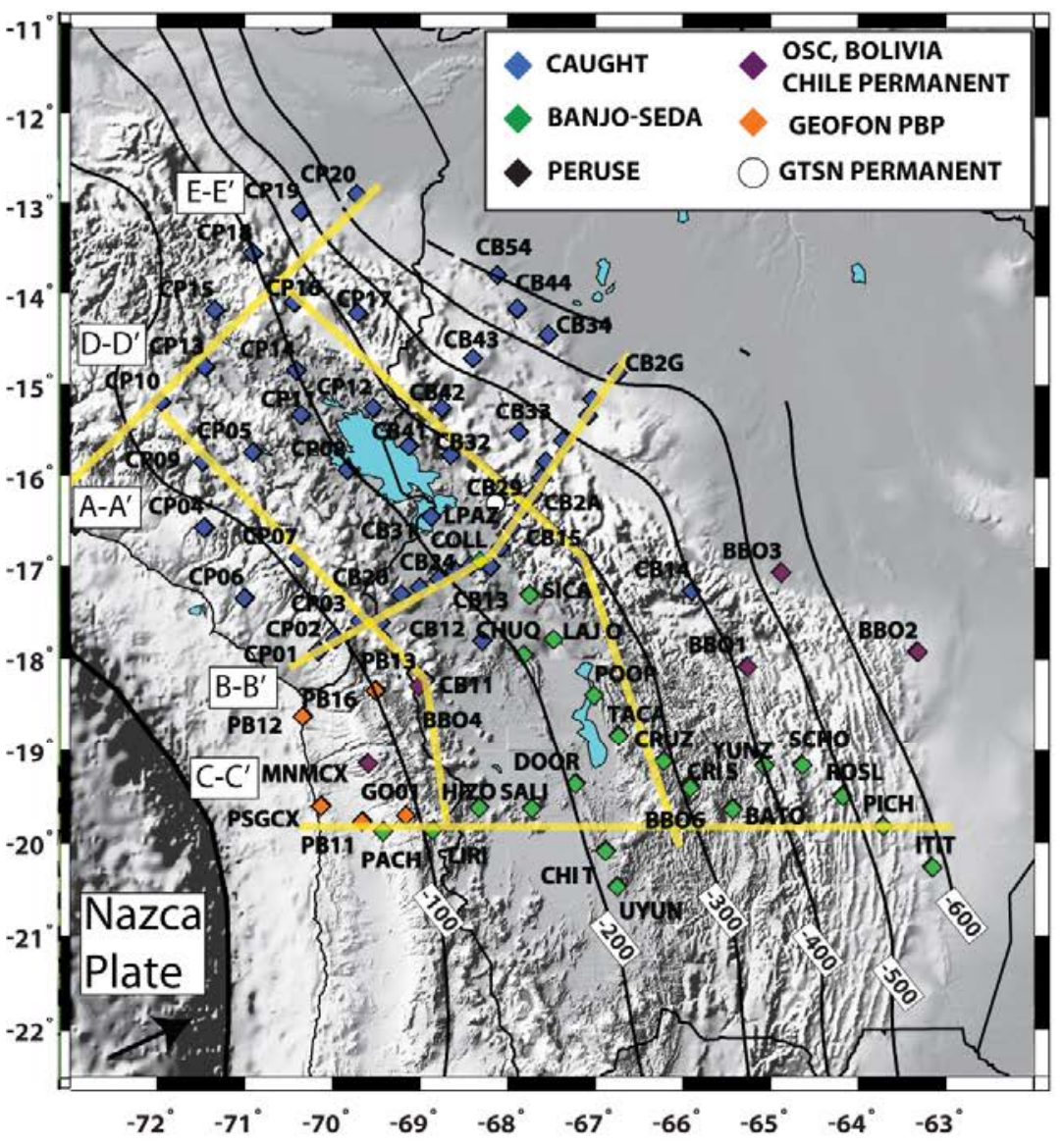

b)

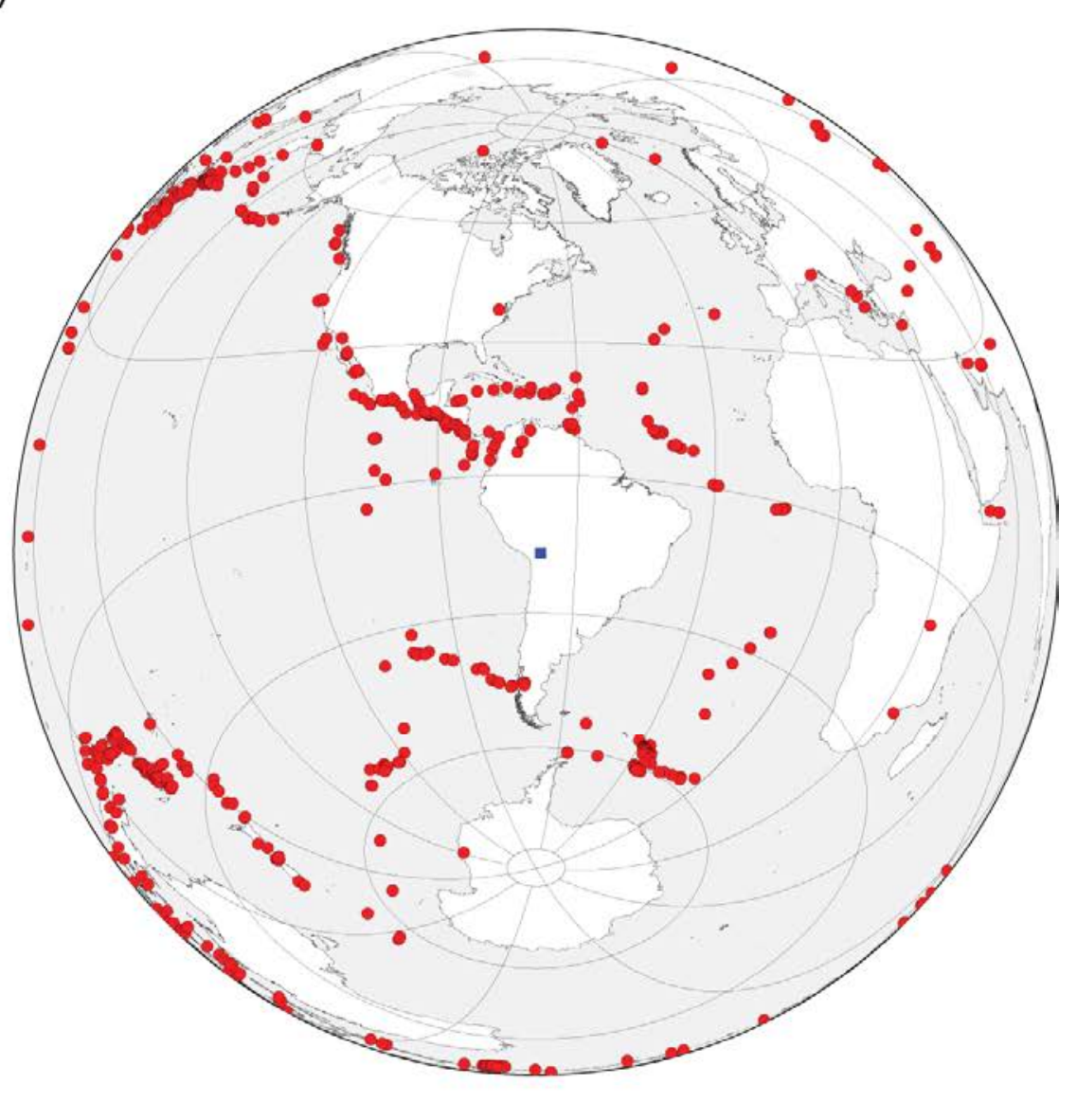

Figure 2: a) Map of the seismic arrays from Table 1, and the cross-section locations of receiver function CCP stacks described in the text. Slab contours are plotted based on the slab1.0 model of Hayes et al., (2012). b) Global projection showing the location of the 343 earthquakes recorded by the stations shown in Figure 1 and used for calculation of the teleseismic receiver functions used in this study (list available in Supplemental Table T1). 

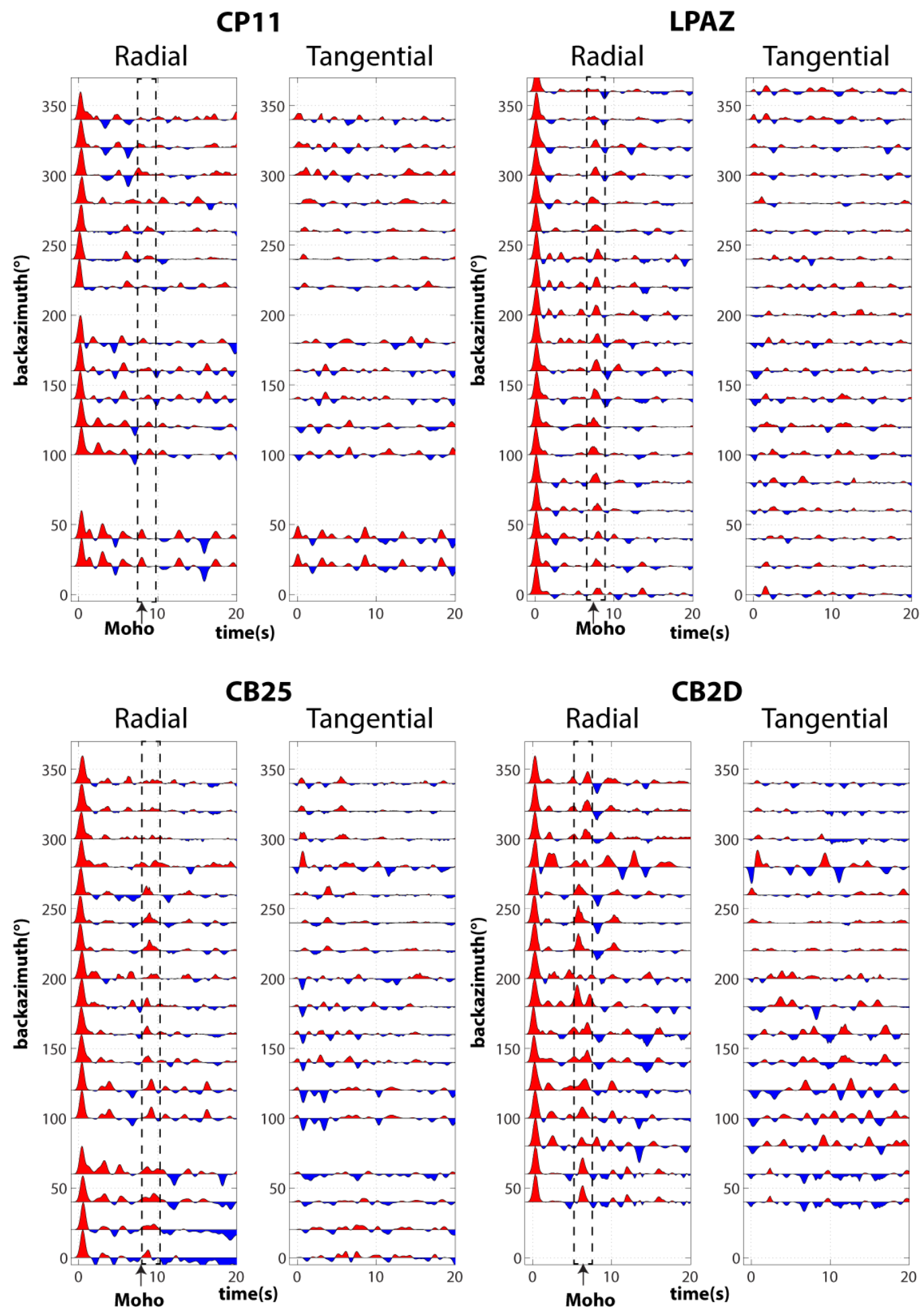

Figure 3: Back-azimuth receiver function plots for four sample stations along the dense portions of the CAUGHT array. The three CAUGHT stations (CP11, CB25, CB2D) show similar backazimuth coverage to the permanent GTSN station LPAZ; Moho arrival picks are outlined on the radial waveforms. An unstacked version can be found in Supplemental Figure S1. 


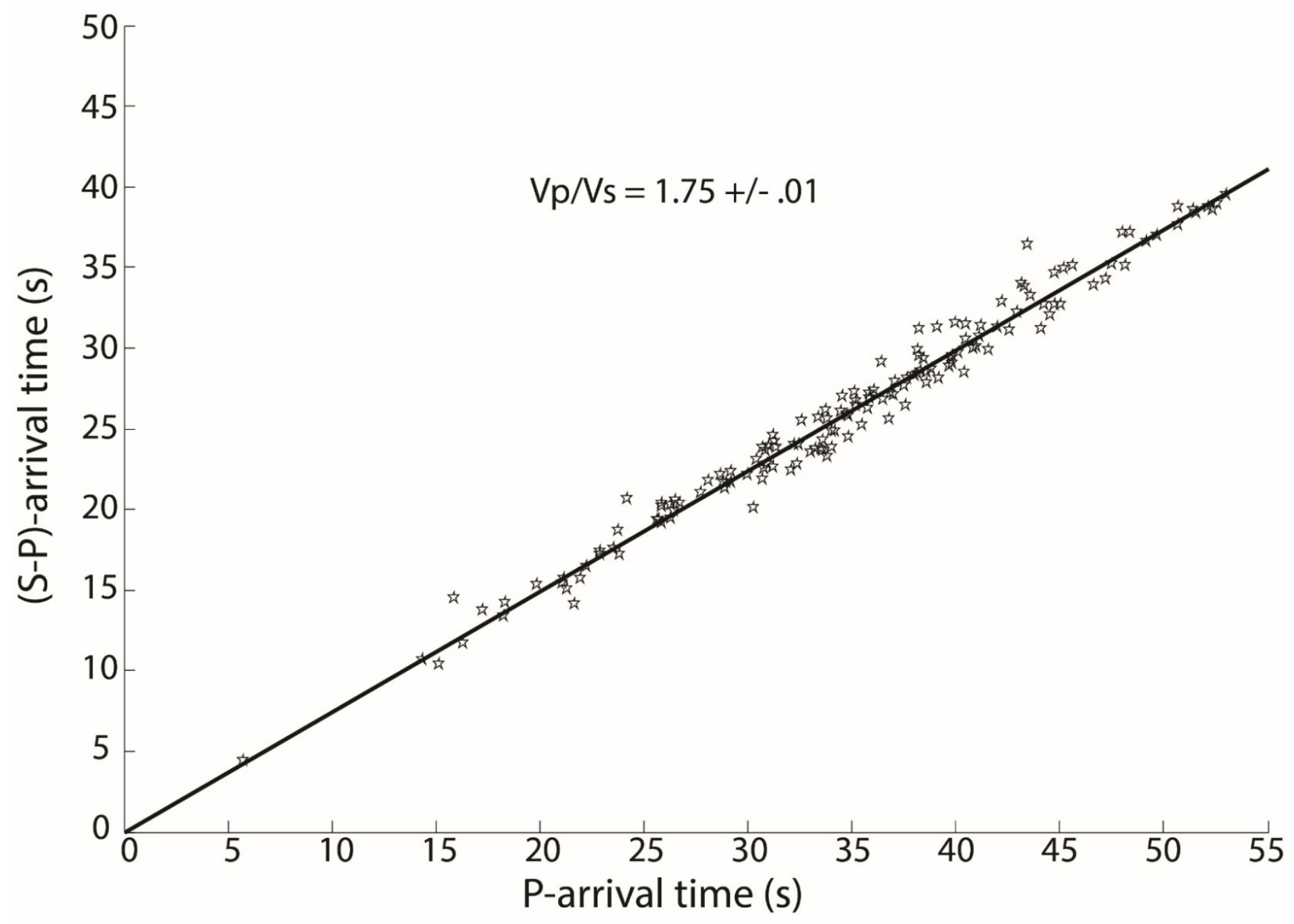

Figure 4: Wadati diagram using 9 local events recorded on the CAUGHT network to constrain Vp/Vs. The solid line is a linear regression through the individual event-station points, giving a slope of (Vp/Vs -1) (Whitcomb et al. 1972). Arrival times were removed prior to plotting to obtain an average $\mathrm{Vp} / \mathrm{Vs}$ based on the nine events. 


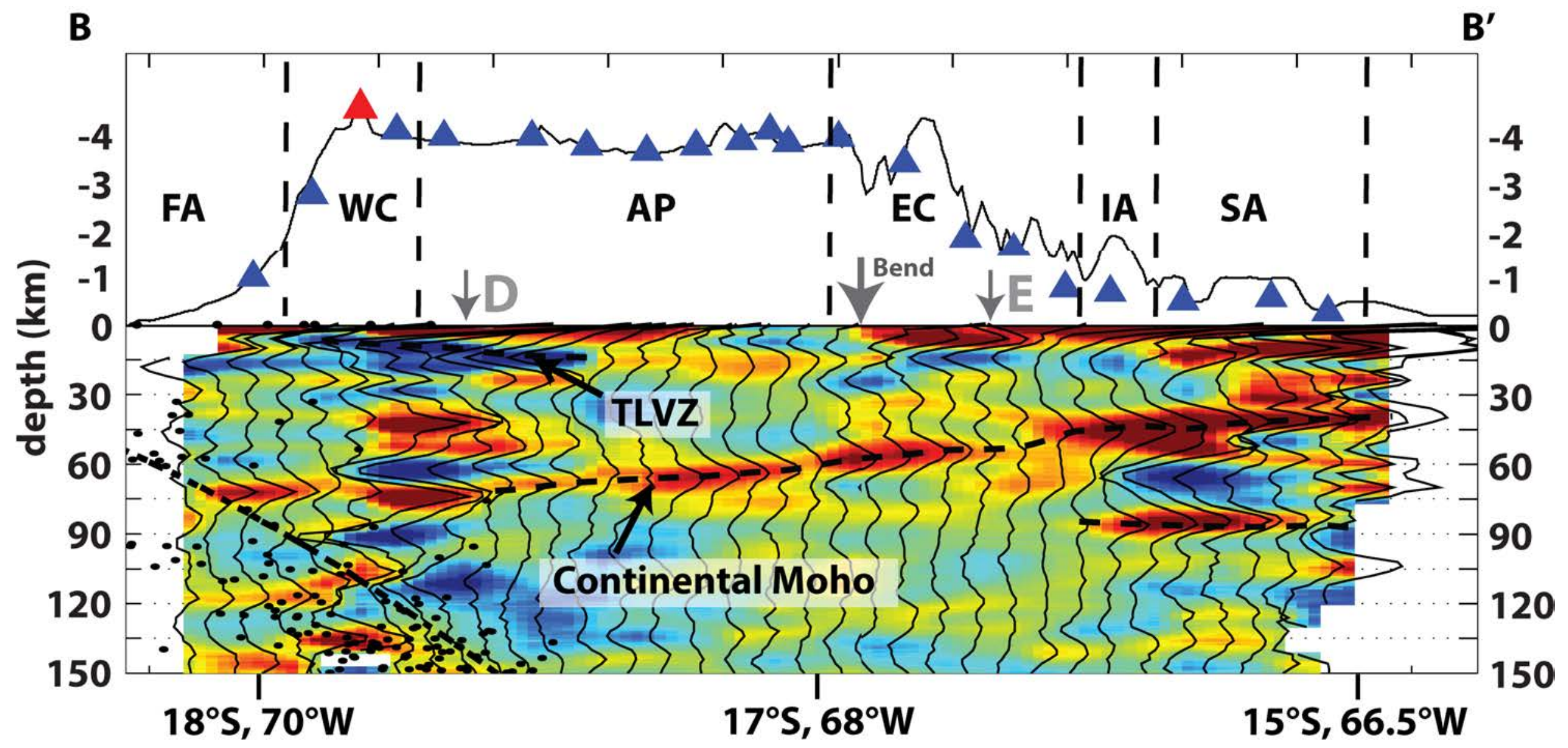

Figure 5: CAP cross-section receiver function stack, at 1-to-1 scale, using a Gaussian pulse-width of a=2.5 and a phase-weighting filter strength of .25. Location of the cross-sections is shown on Figure 1b. The receiver function stacks are depicted as black traces drawn from the surface.

International Seismological Centre earthquake locations (Storchak et al., 2013) are plotted as small black dots. The slab contour (Hayes et al., 2012) is shown as a heavy dashed black line. Positive Ps conversions are shown in red and negative conversions in blue, with the colors saturating at $\pm 15 \%$ of the initial P arrival amplitude. Dark grey arrows show the locations where cross-section lines change direction, while the D and E markers on the section indicate the cross-over locations for the D-D' and E-E' line, respectively. Abbreviations for topographic provinces are same as in Fig. 1. $\mathrm{TLVZ}=$ top of low velocity zone. Bin spacing for the line is $15 \mathrm{~km}$ along the section, and $30 \mathrm{~km}$ perpendicular to the section. A phase-weighting comparison image is available (Supplemental Figure S3). 
a)

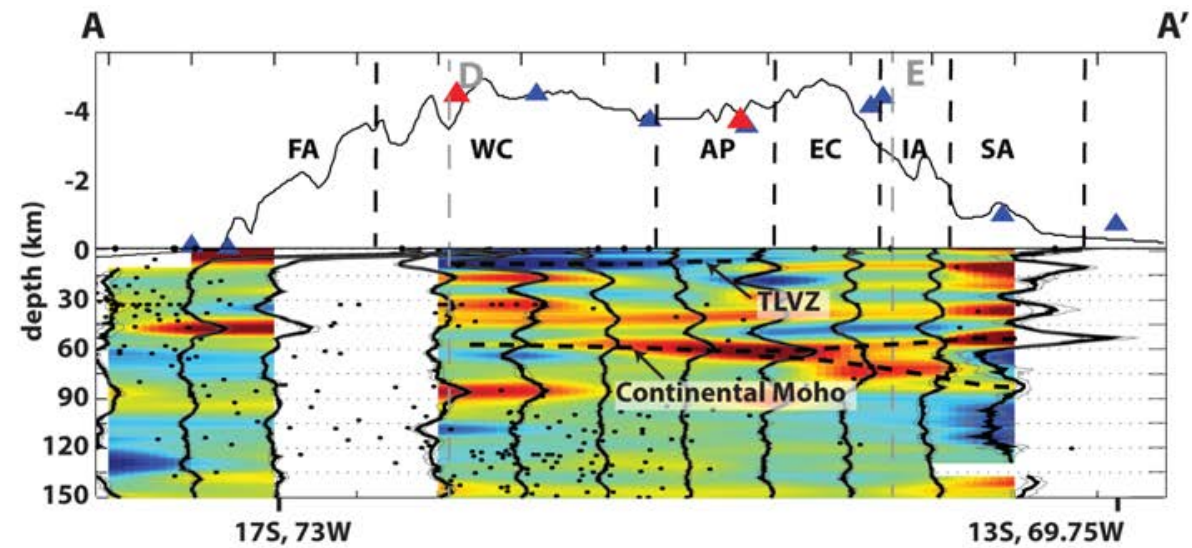

b)

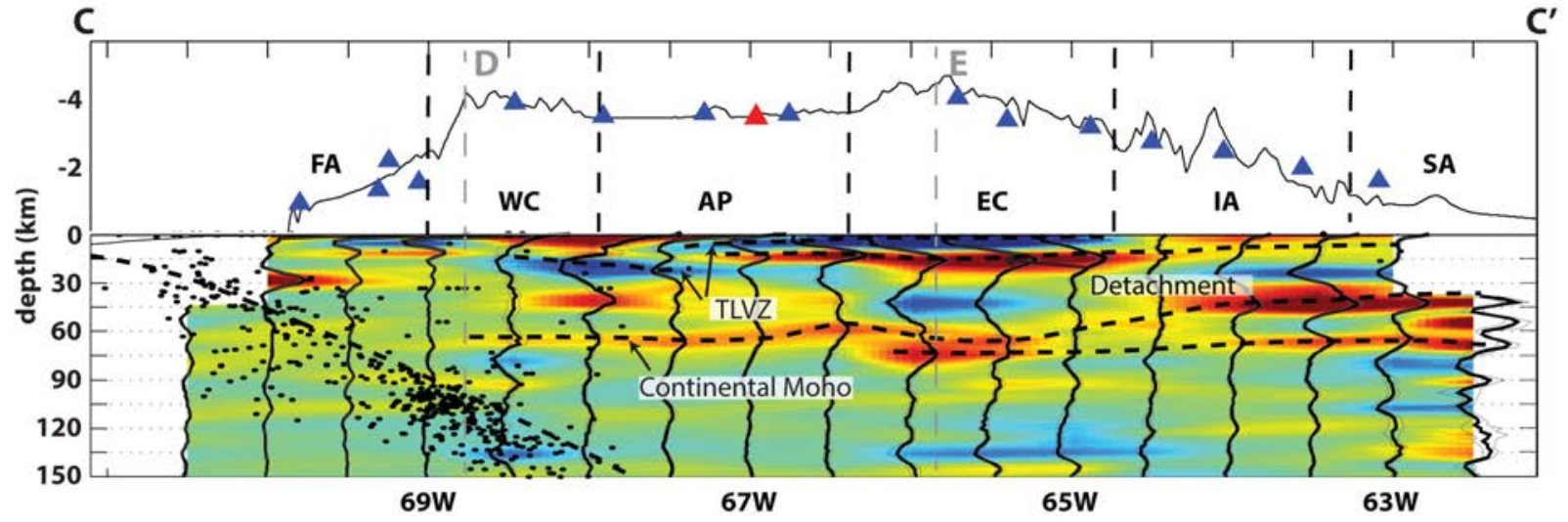

c)
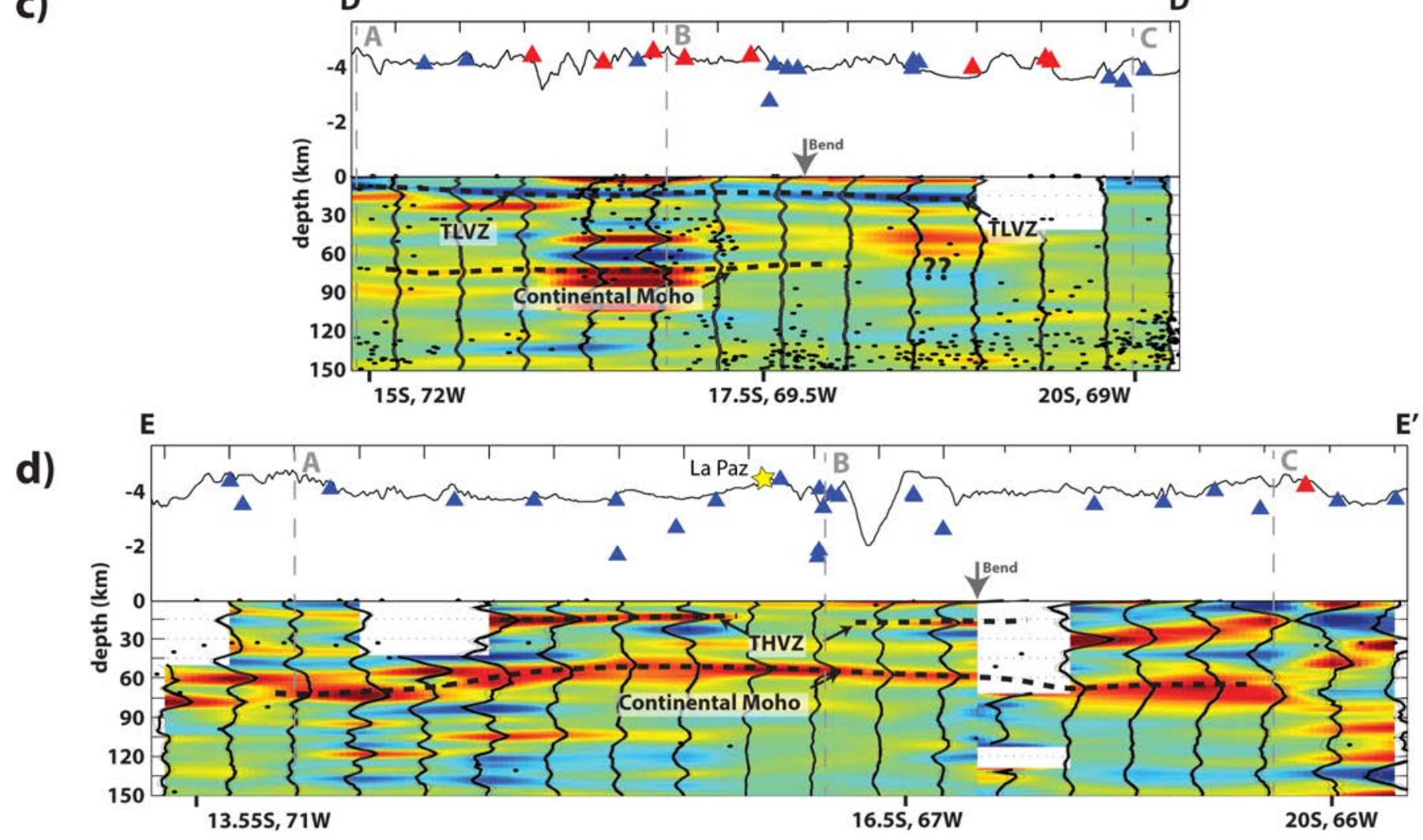

Figure 6a-d: Cross-section CCP receiver function stack, at 1-to-1 scale, using a Gaussian pulse-width of a=2.5 and a phase-weighting filter strength of .25. Labels are the same as in Figure 5, with locations of the lines shown in Figure 1b. Cross-section crossover locations are marked on lines B-B' and C-C'. THVZ = top of high velocity zone, other abbreviations same as figure 5 . Bin spacing for these sections is $50 \mathrm{~km}$ both along and perpendicular to the section. 


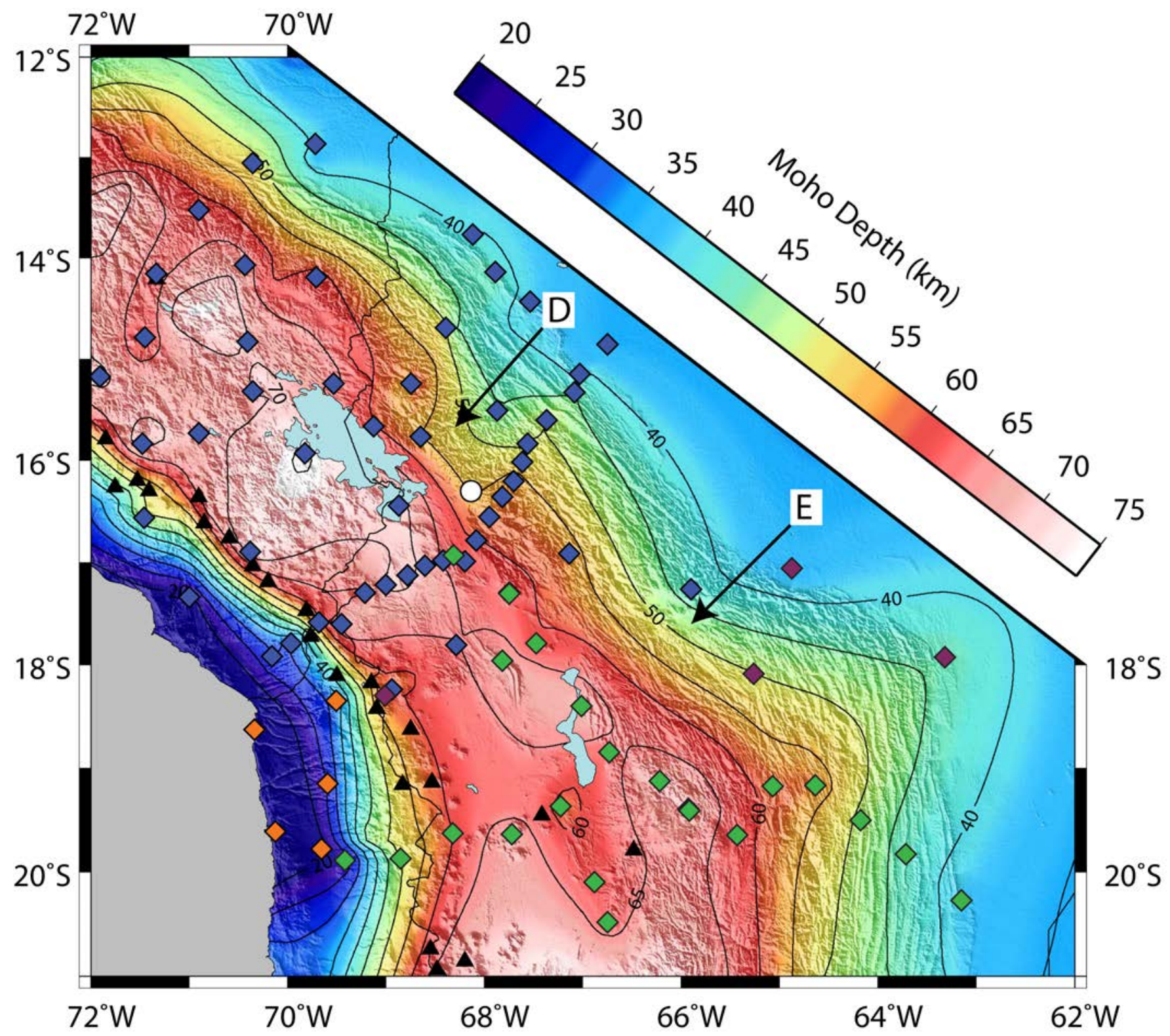

Figure 7: Depth to Moho map, relative to sea level, derived from our receiver functions at the individual stations and contoured using a nearest neighbor interpolation algorithm. Contours are drawn every $5 \mathrm{~km}$ until reaching the $40 \mathrm{~km}$ contour. The forearc and foreland are constrained using gravity measurements from Tassara et al., (2006). Anomalies D and E correspond to anomalies D and E marked on Figure 9. The bins used to derive this map are depicted in Supplemental Figure S2. 


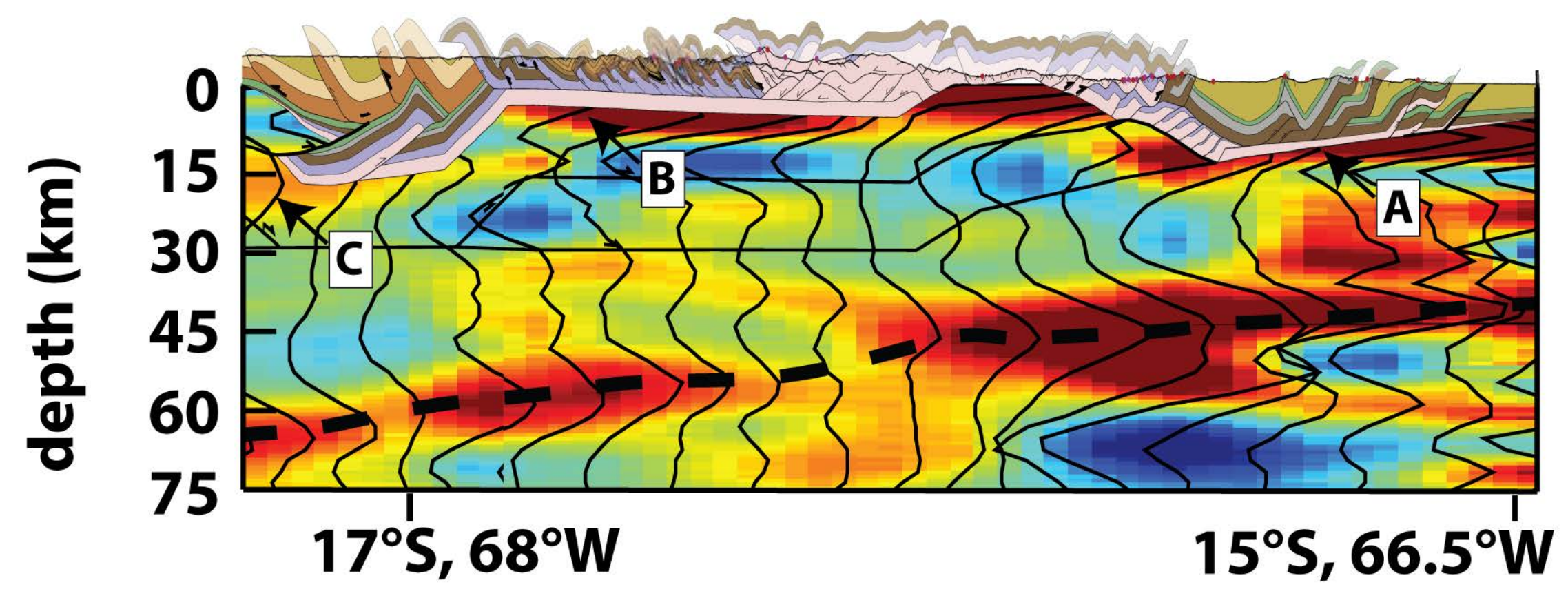

Figure 8: CCP stacked receiver function cross-section overlain with the balanced cross-section of McQuarrie, et al., (2008) to a depth of $75 \mathrm{~km}$. Images are at a 1-to-1 scale and aligned based on tectonic province information from McQuarrie, et al., (2008). Anomalies $\mathrm{A}, \mathrm{B}$ and $\mathrm{C}$ are all positive arrivals corresponding to transitions from low to high velocity that we interpret as the location of basement rock. 


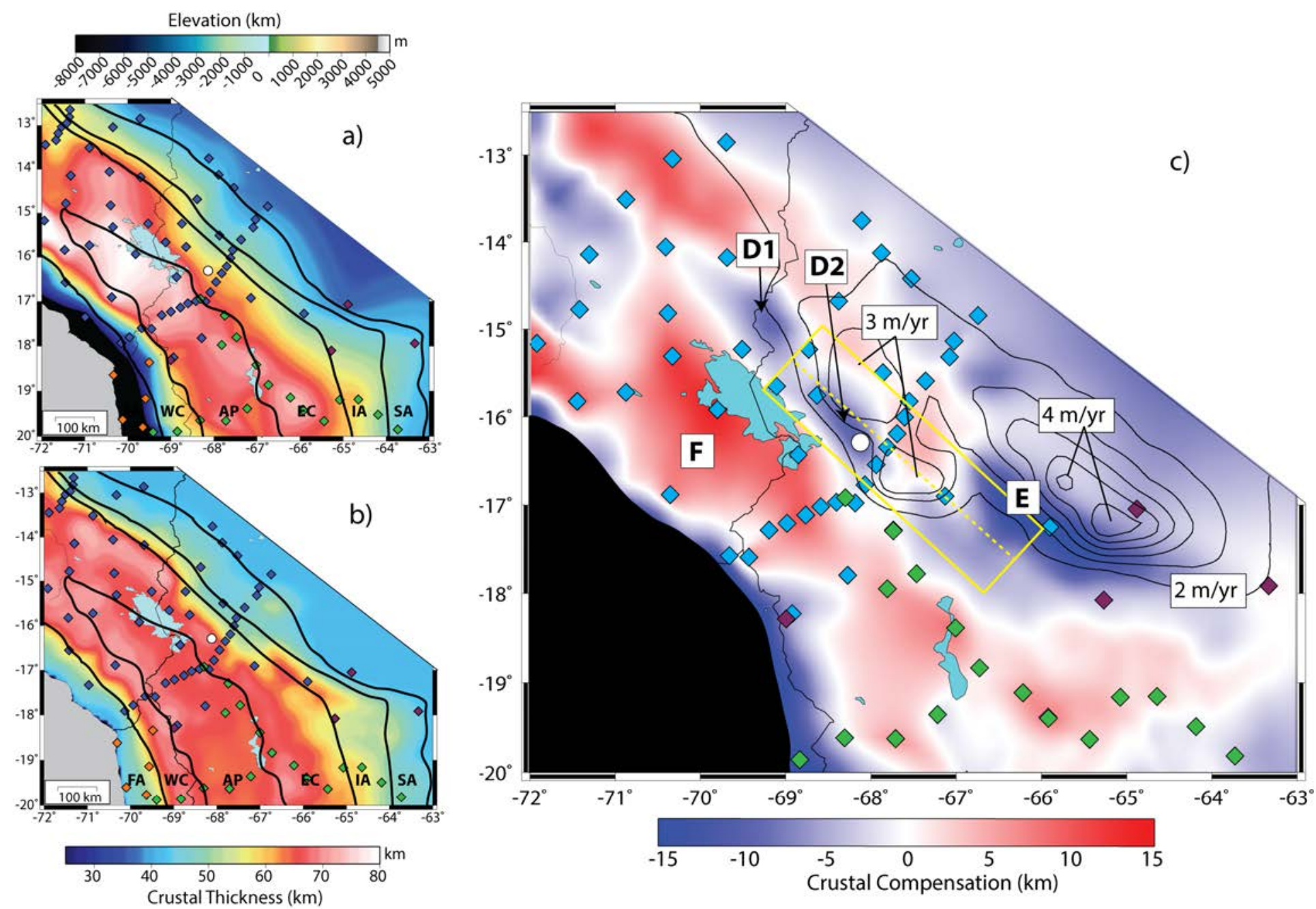

Figure 9: Crustal thickness maps calculated from a) receiver functions and b) Airy isostatic compensation depth for $100 \mathrm{~km}^{2}$ filtered topography. c) Crustal thickness residual map created by subtracting the predicted Airy isostatic thickness using the filtered topographic model $\left(100 \mathrm{~km}^{2}\right)$ from the observed thickness based on receiver functions. Also plotted are contoured precipitation data taken from the TRMM 3B42 database (1998-2013) at contour intervals of 0.2 meter per year. Crustal residual information in the 
forearc has been omitted due to lack of constraints from the observed receiver functions. Anomaly F, in the Altiplano, is an area with thicker than expected crust, while anomalies D1, D2, and E are thinner than our Airy isostasy calculations would predict. 


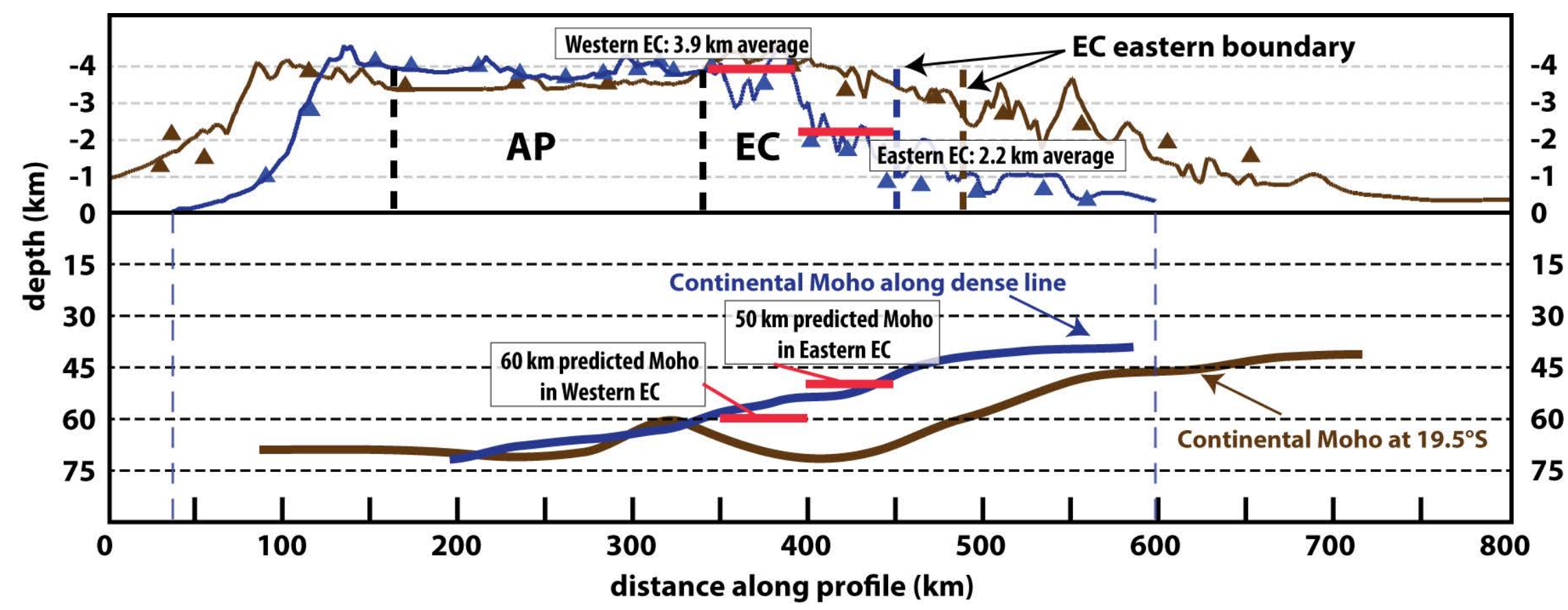

Figure 10: A comparison of depth to Moho and topography profiles along two cross-sections of the Central Andes. The cross-section in brown is at $19.5^{\circ} \mathrm{S}$, the BANJO-SEDA line, and the cross-section in blue is the dense CAUGHT line near La Paz, Bolivia. The cross-sections are aligned along the Altiplano-Eastern Cordillera boundary. Note the difference in the depth to Moho beneath the Eastern Cordillera and the difference in topographic profile along the two cross-sections. The vertical exaggeration below sea level in this image is $2: 1$. 